\title{
EL ROMANCE EN LOS DOCUMENTOS DE LA CATEDRAL DE TOLEDO (1171-1252): LA ESCRITURA*
}

\author{
PEDRO SÁNCHEZ-PRIETO BORJA
}

Universidad de Alcalá

\section{INTRODUCCIÓN}

1.1. El tema que aquí me propongo presentar y explorar en sus líneas más destacables es aparentemente clásico, en tanto versa sobre el castellano de Toledo. Sobre la real o supuesta primacía lingüística de Toledo no es poco lo que se ha escrito, y me atrevo a decir que se convirtió en un tópico incluso entre los propios habitantes de la ciudad. Y a ese tópico se han asociado progresivamente otros, de los que no es el menos importante el del entronque mozárabe del habla toledana, pero también cabe señalar la identificación de ésta con el castellano alfonsí, al menos en algunos de sus rasgos definitorios; además, se ha contrapuesto el habla de Toledo a la de Castilla la Vieja, en lo cual la bibliografía del siglo XX tomó como arranque las consideraciones de los propios tratadistas de los siglos XVI y XVII. Es éste un tema necesitado de profunda revisión, porque algunos de los planteamientos a los que acabo de hacer referencia, en particular los dos primeros, no han tenido apoyo empírico suficiente. Antes al contrario, el castellano de Toledo no han sido considerado en sí mismo asunto de investigación en el marco de la historia de la lengua española, sino sólo como ilustración parcial de la supuesta influencia mozárabe, de los usos alfonsíes o del conservadurismo frente a las innovaciones castellanoviejas. Por ello pretendo una interpretación histórica completa y por ello esta investigación se enmarca en una línea que va de la reconquista a la actualidad. Además, si antes el examen de la documentación se veía como la posibilidad de deducir directamente rasgos de la lengua de uso, en las últimas tres décadas diversos estudios han puesto el acento en cómo la valoración lingüística de los

\footnotetext{
* Este trabajo se ha llevado a cabo con financiación del Ministerio de Educación y Ciencia (Proyecto HUM2006-04767/FILO: «Edición y estudio linguiístico de los documentos medievales de la catedral de Toledo»).
} 
datos que nos proporcian los textos ha de hacerse en el marco de la filología, y sobre todo en el de las relaciones entre lengua hablada y lengua escrita.

La pervivencia de los mentados lugares comunes ha ido asociada a una visión fuertemente ideologizada, de la que no escaparon algunos de los grandes maestros de nuestra filología, empezando por Menéndez Pidal, quien consideró una constante histórica la primacía castellano-norteña en la evolución lingüística, tanto en sentido «horizontal», frente a los otros dos dialectos centrales (leonés y aragonés), como «vertical», frente al castellano de Toledo y, al menos en principio, frente a Andalucía ${ }^{1}$.

El estudio que aquí planteo es ambicioso, y, desde luego, no intentaré agotar todas sus posibilidades. Creo más bien que es un campo abierto, y que se asoma a nuevos panoramas más y más amplios de la historia de la lengua. Por razones de espacio, aquí abordaremos la evolución de la escritura en la documentación toledana, y dejamos para más adelante la caracterización lingüística (fonética, morfológica, sintáctica y léxica) de esos documentos.

\section{LOS COMIENZOS Y COMIENZOS Y CONFIGURACIÓN DE LA ESCRITURA RO- MANCE. ESTADO DE LA CUESTIÓN}

Muchos textos de nuestra historia literaria y cultural se han vinculado a Toledo. En el período que ahora nos interesa queda incluido el Auto de los Reyes Magos. Argumentos a favor del toledanismo del Auto fueron ya señalados por Lapesa. La obra se copió en un códice de la catedral que contiene glosas al Cantar de los cantares y el comentario a los Trinos de Jeremías debidos a Gilberto de la Porrée. Los intentos de datar la obra son poco firmes (tampoco lo es la datación del códice; y habría que empezar por demostrar que la letra es del tipo empleado en el entorno del arzobispo o del cabildo de la catedral). Menéndez Pidal ${ }^{2}$ situó el códice latino que lo contiene en el s. XII, y la letra

1 Las posturas previas pueden, a veces, condicionar negativamente la investigación. Creo preferible una suspensión provisional del juicio que permita captar los datos de manera completa, y que nos disponga adecuadamente para interpretarlos. Por otra parte, no puede decirse que los «pre-juicios» hayan desaparecido de la investigación reciente. Ejemplo es la postura de Roger Wright sobre el papel que otorga al nacionalismo en el nacimiento de la escritura romance, por encima de otros factores como la necesidad de que los textos se entendieran: «el nacionalismo es una enfermedad mental» (El Tratado de Cabreros (1206): estudio sociofilológico de una reforma ortográfica, London, Queen Mary and Westfield College, 2000, pág. 120). O bien que, como dice el mismo autor, la consideración nueva de la escritura «aparentemente latina» empleada en los documentos hispánicos permita salvar la reputación cultural de la Península de los siglos altomedievales (pág. 19). No creo que a estas alturas tenga que ser ese el objetivo, pero, puestos a salvar esa reputación, mejor referirnos a la producción de los mozárabes cordobeses en latín, o a la aportación de la cultura árabe (cfr. Juan Vernet, Lo que Europa debe al Islam de España, Barcelona, El Acantilado, 1999).

2 Obras completas de R. Menéndez. Pidal, XII Textos medievales españoles. Ediciones críticas y estudios, Madrid, Espasa-Calpe, 1967 (el Auto lo publicó por vez primera en Revista de Archivos, Biblioteca y Museos IV, 1900). 
del Auto a principios del s. XIII. Lapesa habla de un «copista nativo y poco posterior» ${ }^{3}$.

El Auto de los Reyes Magos es un texto significativo que cabe vincular inequívocamente a Toledo. Pero ¿cómo empieza la escritura romance en la ciudad del Tajo? Antes de intentar responder a la cuestión conviene plantear el problema en el marco más amplio de la escritura romance y, sobre todo, de la escritura castellana.

Mucho se ha escrito en las últimas décadas sobre el nacimiento de la escritura romance, hasta el punto de que puede decirse que se ha desplazado el foco de atención desde el examen de los usos vernáculos (en tanto podían reconstruirse para la lengua hablada) hacia los usos escritos. Puntos de vista muy diversos se han sucedido, y ponen el acento en los aspectos socioculturales e las implicaciones históricas del hecho de escribir, pero también en la relación entre grafía y fonética ${ }^{4}$. Es innegable que los «orígenes del español escrito», como dice Hernández ${ }^{5}$, han sido objeto de nuevas investigaciones y hoy ya se puede decir que ha habido un cambio sustancial del panorama.

\subsection{La diferenciación entre latín y romance}

Para centrar rápidamente el problema diré que, obviamente, no es lo mismo el nacimiento de las lenguas romances que el comienzo de la escritura romance. El primero se vincula a la aparición de rasgos que no siendo ya latinos tienen continuidad en las lenguas romances. La segunda cuestión implica el empleo de un código ortográfico innovador que refleje de manera más o menos directa la pronunciación románica. Se ha destacado que no todos los niveles de la lengua paticipan de una evolución simultánea. Y los romanistas coinciden en la prioridad cronológica de los rasgos sintácticos, lo que tendrá su importancia desde el punto de vista de la escritura, pues el patrón sintáctico puede ser uno de los criterios para valorar la presión del romance en textos latinos, aunque no ha sido este el criterio tradicional ${ }^{6}$. Desde los conocidos tra-

\footnotetext{
${ }^{3}$ Rafael Lapesa, «Mozárabe y catalán o gascón en el Auto de los Reyes Magos», en Miscellània Aramon i Serra, Barcelona, Curial, 1983, págs. 277-294.

${ }^{4}$ Las referencias bibliográficas son ya innumerables. Aparte de muchos trabajos conocidos de los historiadores de la lengua, contiene útil información sobre los aspectos sociales de la escritura Antonio Castillo y Carlos Sáez, «Paleografía versus alfabetización. Reflexiones sobre la historia social de la cultura escrita», Signo, 1, 1994, págs. 133-168.

${ }^{5}$ Art. cit. en n. 25 .

${ }^{6}$ A los conocidos trabajos de Veikko Väänänen y Joseph Herman (selecta bibliografía en El latín Vulgar, Barcelona, Ariel, 2001; ed. original Le latin vulgaire en Presses Universitaires de France, 1975), habrá que añadir, para nuestro ámbito sobre todo, de Ángel López García, Cómo surgió el español. Introducción a la sintaxis histórica del español antiguo, Madrid, Gredos, 2000.
} 
bajos de Wright ha sido camino transitado por no pocos investigadores, aunque es de justicia reconocer antecedentes ${ }^{7}$.

La manifestación «consistente» de la escritura romance castellana es tardía. Para algunos, el primer documento plenamente romance es la carta-puebla de Villa Algariva, de 1191 (aunque en esto de señalar prioridades toda precaución es poca, como se verá). Pero sin esperar a estas formas coherentes y plenamente consolidadas, ciertos rasgos del latín medieval obedecen a un dictado románico, y no sólo en el plano sintáctico. En los códices medievales pueden rastrearse usos romances desde muy antiguo ${ }^{8}$. Y los estudiosos de la cultura bíblica altomedieval señalan la confección de códices en la península ibérica escritos hispanice o hispanissime ${ }^{9}$.

Curiosamente, y contra lo que se esperaría, el latín escrito por los mozárabes de Al-Andalús, no parece mostrar rasgos debidos a la presión del romance. Herrera Roldán ${ }^{10}$ observa que, aunque el latín de los mozárabes está muy alejado del clásico, la inmensa mayoría de los rasgos descrepantes que muestra están «previstos» por el latín vulgar (por descontado, faltan del todo rasgos caracterizadores del mozárabe de las jarchas, como el conocido mivi). Ha de destacarse el sesgo «bíblico» de este latín, según se aprecia especialmente en el léxico, por la profileración de helenismos tan propios de la Vulgata (y de la Vetus latina) ${ }^{11}$, y de hebraísmos ${ }^{12}$. Resulta interesante, pero más bien por lo negativo, la lista de hispanismos y vulgarismos, pues son prácticamente todos antiguos (pág. 133).

El grado de anquilosamiento de este latín se explica por las peculiaridades socioculturales en que vivieron los cristianos de Al-Andalús. Pero nadie negará que es latín, tanto por los usos gráficos (no del todo valorables por la interposición de copias) como por las opciones léxicas (en la mayoría de los casos), y, sobre todo, por la sintaxis. Como esta es la cuestión menos obvia y más compleja conviene detenerse en ella; la convergencia sintáctica entre el latín medieval y el romance es un fenómeno que en muchos aspectos está enmascarado por los moldes morfológicos... pero, con todo, no muestran ni de lejos el

\footnotetext{
7 Entre otros, Juan Antonio Frago, «El paso del romance a la escritura: problemas culturales y lingüísticos», Renovación intelectual del occidente europeo (siglo XII). 24 Semana de estudios medievales, Estella, 14-18 julio 1997, Pamplona, Gobierno de Navarra, 1998, pág. 65.

${ }^{8}$ Es algo bien sabido. Cfr. Manuel Alvar y Sebastián Mariner, «Latinismos», Enciclopedia Lingüística Hispánica, I, Madrid, 1960; también Joan Bastardes, «El latín medieval», art. cit.

9 Véase Jean Gribomont, «Conscience philologique chez les scribes du haut moyen âge», $L a$ Bibbia nell'Alto Medieoevo, Spoleto, 1963, págs. 601-630.

10 Pedro Herrera Roldán, Cultura y lengua latinas entre los mozárabes cordobeses del siglo IX, Córdoba, Servicio de Publicaciones de la Universidad de Córdoba, 1995.

11 Cultura y lengua latinas..., op. cit., pág. 132, diaconus, episcopus, presbyter, angelus, daemon, anatherma, heresis, etc.

12 Cultura y lengua latinas..., op. cit., abbas, cherubin, Geenne 'el infierno'.
} 
grado de solapamiento con la sintaxis romance de los documentos notariales a partir del s. X. La complejidad retórica de este latín es notable.

Menédez Pidal vio numerosísimos rasgos romances en documentos de los siglos $\mathrm{X}$ al XII, principalmente del NO peninsular. ¿En qué lengua estaban estos documentos? Es bien sabido que este autor postuló la existencia de un «latín arromanzado» que se hablaba todavía en esos siglos. Wright los ve como documentos romances escritos en manera no reformada, es decir, anterior a la lectoescritura por el procedimiento de las litterae. De este modo, según ha repetido tantas veces Wright, latín y romance no son dos lenguas diferentes antes del arraigo en España de la reformas carolingias, sino que simplemente hay dos modalidades de la misma lengua, el romance, que se habla desde hace tiempo, y que se escribe a la manera tradicional. La palabra escrita era una especie de logograma que remite globalmente a la imagen acústica romance, de acuerdo con un procedimiento de aprendizaje que se da en lenguas de escritura tan poco fonética (si se compara con el español) como el inglés ${ }^{13}$. El nacimiento de la escritura romance exige una renovación del latín que haga que por su léxico, sintaxis, morfología y fonética el texto no sea comprensible cuando se leyera según el nuevo uso, es decir, dando a cada letra un correlato fónico. De ahí que la escritura romance naciera en los centros donde se había instaurado la mejor latinidad, es decir, allí donde la necesidad de compresión de los textos leídos hiciera insuficiente la lectura «correcta» de los textos escritos, ahora sí, a la manera latina. Estos planteamientos han dado lugar a una conocida polémica ${ }^{14}$. A mi entender, la principal aportación de Wright es de orden metodológico, y puede resumirse así, p. ej., a propósito de las Glosas Emilianeneses: la ortografía innovadora implica pronunciación innovadora; la ortografía conservadora no implica pronunciación conservadora. Este planteamiento no es del todo nuevo, y ya Lindley Cintra lo expuso con toda claridad a propósito de la interpretación que Menéndez Pidal hace de los documentos de los siglos $\mathrm{X}$ al XII ${ }^{15}$.

${ }^{13}$ La obra más lograda de Roger Wright es Latín tardío y romance temprano, Madrid, Gredos, 1989 (traducción de Late Latin an Early Romance in Spain and Carolingian France, Liverpool, Arca, 1982).

${ }^{14}$ Un buen resumen en María José Quilis, Orígenes históricos de la lengua española, Valencia, Universitàt de València (Anejo n. ${ }^{\circ}$ XXXIV de la Revista Cuadernos de Filología), 1999.

${ }^{15}$ Luís Felipe Lindley Cintra, «Langue parlée et traditions écrites au moyen-âge (Péninsule Ibérique)», Atti del XIV Congresso Internazionale di Linguistica e Filologia Romanza (1974), I, Napoli, 1978, págs. 463-472. 


\subsection{Los primeros documentos romances oficiales. Las Paces de Cabreros}

El considerado hasta ahora como primer documento oficial de la cancillería castellana en romance es el conocido como Paces de Cabreros ${ }^{16}$, de 1206, acuerdo entre Alfonso IX de León y Alfonso VIII de Castilla («el de las Navas») en la villa vallisoletana de Cabreros. Por él se reconocen los derechos sucesorios en León de Fernando (futuro Fernando III), hijo del ya disuelto matrimonio entre Alfonso IX y Berenguela, hija de Alfonso VIII de Castilla, matrimonio que el Papa Inocencio III había condenado reiteradamente por estar «sub huius incesti specie». El documento fue publicado parcialmente por Menéndez Pidal ${ }^{17}$, y de manera completa por González ${ }^{18}$. Recientemente, Wright ha estudiado el texto, y ofrece transcripción paleográfica completa de sus dos representantes, el del Archivo de la Catedral de León (MS 27) y el del Archivo de la Corona de Aragón (Cancelleria Pergamins, Pere I, n. ${ }^{\circ}$ 227, carpeta 61) ${ }^{19}$.

La crítica ha notado que la lengua de las Paces es castellana, con algunos galleguismos, según Morala ${ }^{20}$. Lo primero es claro; lo segundo, poco probable. $\mathrm{Y}$ es que la única forma susceptible de interpretarse como galleguismo es $c a$ vaeros, se supone que por «cavaleros». Nótese, sin embargo, que una vez los dos ejemplares traen caveros, palabra, no hace falta decirlo, usual en la documentación castellana al menos durante el s. XIII ${ }^{21}$. Las diferencias entre las mal llamadas «versiones» se deben a variación en el código gráfico empleado, y solo en algunas ocasiones a que sus valores fonéticos sean distintos (con la dificultad añadida de que el ejemplar castellano sólo es accesible por copia). Así, exir en el ejemplar de la Catedral de León (ACL), frente a esir en el del Archivo de la Corona de Aragón (ACA). Filios (en los dos) podría apuntar hacia la fonética leonesas si no fuera porque los dos ejemplares coinciden en meiores. Puestos se lee en ACL, postos en ACA, pero pues en los dos. Más consistente nos parece forzia en copia leonesa por forza en $\mathrm{ACA}^{22}$. Pero más

\footnotetext{
${ }^{16}$ Prefiero el título «Paces de Cabreros» al de Tratado que ahora aparece al frente de la edición que hace Roger Wright, por aparecer aquella palabra en la primera línea del documento («esta es la forma de la paz»).

17 Ramón Menéndez Pidal, Rafael Lapesa y María Soledad de Andrés, Crestomatía del español medieval, Madrid, Gredos, 1965.

${ }_{18}$ Julio González, El reino de Castilla en la época de Alfonso VIII, Madrid, CSIC, 1960.

19 Roger Wright, El Tratado de Cabreros, op. cit.

20 José Ramón Morala, «El leonés medieval: lengua escrita y lengua hablada», Actes du XXe Congrès International de Linguistique et Philologie Romanes, ed. Gerold Hilty, Tübingen, Francke, 1992, págs. 519-530, esp. 529.

${ }^{21}$ Aparte está el hecho de que teniendo el étimo -LL- mal podría explicarse por el gallego la pérdida de la geminada.

${ }^{22}$ El tratado de Cabreros, op. cit., pág. 83.
} 
bien tenemos lo contrario, preferencia por -ça o -za en el ejemplar de León (convenenza, sentenza) frente a convenencia, sentencia del ejemplar del ACA (se han de tener en cuenta, como nota Wright, la gran variación gráfica, especialmente en «conveniencia» (una vez escrita -cia en el ejemplar leonés y -za en el castellano). Tal vez se explique como peculiaridad de la copia del ACA 52 drecho $^{23}$. Contradice el uso leonés la escritura reiterada en ACL del diptongo $u e$, pues en la documentación de la primera mitad del s. XIII es habitual ver transcrito $i e$, mientras que se pone $o$ en vez de $u e^{24}$.

Wright cree que hubo discusiones enconadas acerca de la aceptación de las reformas. En particular, Diego García era opuesto al uso del romance, mientras que el arzobispo Martín López de Pisuerga sería partidario. No es seguro que existiera un verdadero conflicto entre ambos personajes. Como demuestra F. J. Hernández ${ }^{25}$, no es que Diego García y López de Pisuerga se disputaran la cancillería. El arzobispo la tenía «casi por derecho hereditario», nominalmente, pero el canciller de oficio era Diego. Más atendible resulta, en cambio, explicar, como hace Wright, la ausencia de documentación cancilleresca entre 1206 (o mejor 1207, año de las Cortes) y 1223, antes de la unificación de Castilla y León, por la actitud hostil de Jiménez de Rada (aunque más adelante será necesario revisar esta cronología). En realidad creo que la introducción venía de atrás. A la luz de la historia de los nuevos usos tal vez la cuestión no fue tan extremada, y se me antoja, al menos como punto de partida, que las razones prácticas estuvieron por encima de las ideológicas. En esta línea se sitúa Hernández para explicar por qué las Paces de Cabreros se escribieron en la nueva forma romance y no en la tradicional latina. Para el papa Inocencio III, como para su antecesor Gregorio VII, el romance escrito era un código nuevo, no reconocido en el derecho internacional. El derecho canónico se escribía en latín. Las Paces contradecían las repetidas condenas de los papas a la política matrimonial de los reyes castellanos y leoneses. Pero al estar en romance el papa no tenía por qué darlas por existentes. Según Hernández, de este modo sencillo pero ingenioso el documento obligaba a los reinos peninsulares, pero no contravenía las disposiciones papales sobre el matrimonio entre Alfonso y Berenguela y su «ilegítima» descendencia.

${ }^{23}$ En una búsqueda rápida en nuestro corpus Documentos españoles anteriores a 1700 encuentro drecho en documentos aragoneses, navarros, murcianos, guipuzcoanos.

${ }^{24}$ Diptongos en ie veo en el ejemplar leonés en bien, pero ACA ben. Creo que ue es grafía interpretativa de la copia del ACA en «pues morte della», frente a «post morte della» del ejemplar leonés. Pero luego los dos tienen «pues sue morte». Otras diferencias no permiten evaluación firme: dias de León es dies en ACA, que podría ser muy bien una modificación en la copia. Wright explica algunas diferencias por el dictado (ocho/tros, touieren/ouieren, dessos/delos...), pero igual pueden deberse a copia visual, es decir, a «dictado interior».

${ }^{25}$ Francisco Javier Hernández, «Sobre los orígenes del español escrito», Voz y Letra. Revista de Filología, X/2, 1999, págs. 133-166. 
En orden a la reconstrucción del contexto histórico de los comienzos de la escritura cancilleresca, las Paces de Cabreros son un documento fundamental. Ahora bien, en un orden más preciso y atento a las peculiaridades gráficas de la escritura oficial de Castilla ${ }^{26}$, las opciones que podemos suponer mostraría el ejemplar castellano (y que efectivamente muestra el del ACL) no se corresponden del todo con la que será la ortografía dominante en los diplomas oficiales del Reino de Castilla y León (la mal llamada «ortografía alfonsí»). Pero justo es reconocer que las Paces hacen un uso bastante eficaz casi siempre del nuevo código, además de ser muy fonéticas en muchos puntos ${ }^{27}$, casi como surgido de la nada. Será, pues necesario, rastrear cómo pudo llegar a configurarse el código usado ya en 1206 por primera vez, que se sepa, en un documento oficial en las cancillerías de León y de Castilla y cómo ese código se afinó hasta llegar a la estabilidad manifestada luego por los diplomas de Fernando III. En esa forja y en ese acrisolamiento la escritura en Toledo pudo tener algún papel. Para empezar, porque el arzobispo Martín López de Pisuerga fue uno de los promotores de la reunión de Cabreros, si no responsable de que el acuerdo tomara forma romance.

Las Paces plantean no pocas preguntas, y no es la más fácil de contestar la de cómo fue posible escribir en 1206 un documento oficial en romance. Convendrá rastrear la vinculación que se ha señalado algunas veces entre la cancillería real y el Studium Generale de Palencia, y que interesa especialmente para nuestro propósito por la posible «conexión» palentina de la catedral de Toledo (cuestión ésta sobre la que volveremos). En resumen, las Paces de Cabreros no demuestran la existencia de una tradición de escritura romance en la cancillería leonesa. En puridad, tampoco la demuestran en el caso de Castilla, pero la perfilan como una hipótesis necesaria.

\subsection{La llamada «ortografía alfonsí» y sus antecedentes}

En pocos asuntos de nuestra historia lingüística como en el de la configuración de la ortografía medieval han arraigado tópicos tan perdurables. Las ideas tradicionales se han difundido de estudioso en estudioso cada vez en forma más simplificada. $\mathrm{Y}$ es que el estudio de los usos gráficos exige una investigación tan minuciosa, a la vez que un método filológico de tanto rigor que pocos son los que se han tomado la molestia de examinar la cuestión en detalle.

\footnotetext{
${ }^{26}$ Es fundamental distinguir lo que es mera variación ortográfica de los que tiene implicaciones fonéticas. Roger Wright, op. cit., pág. 84, parece meter en el saco de la ortografía rencuralrancura.

${ }^{27}$ Este foneticismo parece en algún caso atender a las peculiaridades locales de la pronunciación, como en el topónimo asturiano «Tineo»: Tineu en la copia del ACL y **neu en la del ACA.
} 
Como afirma R. Santiago en un ensayo por desgracia inédito, un párrafo de la Fonología española de Alarcos resume las ideas generalmente admitidas acerca del castellano alfonsí y su ortografía:

Con la elevación del castellano a lengua cancilleresca se normalizan sus características [...]. Con la regularización ortográfica de Alfonso X ya tenemos datos fidedignos e inequívocos para poder determinar cuál era el sistema fonológico de este primer castellano literario, en el cual, como dijimos, los rasgos originarios del Norte se modificaron en parte al contacto con los rasgos de los dialectos centrales. Tal sistema, consolidado en la región toledana, es el que caracteriza al castellano cultivado hasta el siglo XVI, según lo describe Nebrija. Pero, como veremos, ya en la Edad Media se incuban, en las regiones septentrionales, y se van extendiendo, modificaciones que se generalizan y triunfan en la época moderna ${ }^{28}$.

Amado Alonso coincide en lo fundamental con estas ideas, y le atribuye al Rey Sabio en concreto la distinción entre sibilantes sordas y sonoras (de forma explícita, al menos, la de /s/ y /z/), y señala que fue Nebrija el responsable de que se generalizara la distinción entre las tres parejas de sibilantes en la literatura castellana ${ }^{29}$. Pero ha sido Lapesa quien ha difundido en mayor medida la atribución a Alfonso $\mathrm{X}$ de un sistema gráfico (y no sólo gráfico) de larga vigencia en castellano medieval:

La grafía quedó sólidamente establecida; puede decirse que hasta el s. XVI la transcripción de los sonidos españoles se atiene a normas fijadas por la cancillería y escritos alfonsíes ${ }^{30}$.

Sería interminable la nómina de quienes han repetido, simplificándolas más y más, las ideas tradicionales. Como en tantas otras cuestiones, más matizadas se encuentran las ideas en torno a la ortografía alfonsí en la obra de Menéndez Pidal. Si por una parte habla de «la precisa y sencilla ortografía alfonsí», por otra sitúa ese sistema ortográfico en la época de Fernando III y Alfonso el Sabio y apunta a su forja en los reinados de Alfonso VIII y Enrique I. Otros investigadores llamaron la atención sobre la escasa precisión de las observaciones en torno a la ortografía alfonsí, como Frago, para quien no se habían determinado qué rasgos caracterizaban al castellano alfonsí y a su ortografía ${ }^{31}$.

En el III Congreso Internacional de Historia de la Lengua Española cele-

\footnotetext{
${ }^{28}$ Emilio Alarcos Lloach, Fonología española, Madrid, Gredos, 1965, primera edición, § 157 (págs. 263-264)

${ }^{29}$ Amado Alonso, De la pronunciación medieval a la moderna en español, Madrid, Gredos, 1969, vol. II, págs. 7-8.

${ }^{30}$ Rafael Lapesa, Historia de la lengua española, $9^{\mathrm{a}}$ ed., Madrid, Gredos, 1981, § 63.3. No hará falta insistir en que la pervivencia del llamado sistema alfonsí no se aprecia en los documentos de los siglos XIV y XV.

31 Juan Antonio Frago, Historia de las hablas andaluzas, Madrid, Arco/Libros, 1993, páginas 244-245.
} 
brado en Salamanca en 1993 expuse que la comparación entre los diplomas alfonsíes de Fernando III y Afonso X desmentía con toda contundencia las ideas tradicionales sobre la «ortografía alfonsí» ${ }^{32}$. Los diplomas de Fernando III anticipan claramente los rasgos gráficos (por no decir fonéticos y de otro orden) que manifestaban los escritos de su hijo. La comparación de un buen número de pergaminos demostró que sólo la distinción entre $-c-/-z-,-s s-/-s-$ y $-x-I_{-j-},-g-$ se daba desde los primeros diplomas romances del rey Santo. También puede señalarse como elemento crítico el empleo de $c$ ante $a, o, u$, y de $c$ ante $e, i$; el de $m$ ante $p$ y $b$, entre otros. Pero no puede pretenderse, y no sólo por «inseguridad» gráfica, que estos usos sean sistemáticos. Posteriormente M. Ariza Viguera señala también la prioridad de Fernando III sobre Alfonso X en la ortografía romance ${ }^{33}$. Es paralelo a mi estudio, en cambio, el trabajo inédito de R. Santiago ${ }^{34}$. En él señala cómo documentos de distintas zonas (p. ej., de Santander) anticipan los usos alfonsíes. No obstante, esto justifica según R. Santiago siquiera parcialmente el concepto de «ortografía alfonsí» porque sólo a finales del reinado de Fernando III se empieza a emplear una ce con cedilla $(c ̧)$ claramente diferenciada de la llamada $z$ copetuda, lo que posibilita la distinción entre la sibilante dental sorda y la sonora. En otro lugar me he ocupado de esto, y evidencias hay de que esta distinción es temprana en la cancillería de Fernando $\mathrm{III}^{35}$. Como el rasgo es central para la solidez del sistema gráfico, examinaremos su empleo en la escritura toledana. Otro aspecto destacado por R. Santiago es la enorme extensión que bajo Alfonso X experimenta el empleo del romance. Ello es cierto, pero hemos de preguntarnos en qué modo esto pudo implicar una distinta valoración sociológica (o sociopolítica) y cultural del castellano. Y, claro, la motivación política para el uso del romance es algo que la crítica ha destacado desde hace tiempo. El aspecto más obvio es la necesidad política de llegar a todos los súbditos. Pero esto ya lo vio el rey Santo con toda claridad, cuando en 1241 añade unas disposiciones al Fuero de Córdoba en romance para que puedan entenderlas presentes y venideros, y termina

32 «Sobre la configuración de la llamada ortografía alfonsí», Actas del III Congreso Internacional de Historia de la Lengua Española. Salamanca, 22-27 de noviembre de 1993), editadas por A. Alonso González, L. Castro Ramos, B. Gutiérrez Rodilla y J. A. Pascual Rodríguez, Madrid, Arco/Libros, 1996, págs. 913-922.

${ }^{33}$ Manuel Ariza, «Fernando III y el castellano alfonsí», Estudios de Lingüística y Filología Españolas. Homenaje a Germán Colón, Madrid, Gredos, 1998, págs. 71-84.

${ }^{34}$ Fue presentado en forma manuscrita en el Seminario de Historia de la Lengua Española celebrado en Soria en el verano de 1997. Véase también María Jesús Torrens, «La paleografía como instrumento de datación. La escritura denominada «littera textualis»», Cahiers de Linguistique Hispanique Médiévale, 20, 1995, págs. 345-380.

35 «Para una historia de la escritura en Castilla», Actas del IV Congreso Internacional de Historia de la Lengua Española, La Rioja, 1-5 abril de 1997, editadas por Claudio García Turza, Fabián Bachiller y Javier Mangado, Logroño, vol. I, 1998, págs. 289-301. 
de manera enigmática sancionando la versión del Fuero «que yo mandé trasladar en romance» (nada se sabe de ese romanceamiento, si es que finalmente lo hubo) ${ }^{36}$.

La necesidad de comprensión salta a la vista como motivo en las «posturas»o «cotos» de 1207, salidas de las cortes de Toledo ${ }^{37}$, pues en todo el reino debían conocerse los precios máximos de las mercancías. Y la misma motivación encuentra Wright en el primer documento en romance conocido de la cancillería de Fernando III, que es del 11 de julio de $1223^{38}$. El «mandamiento» de Fernando III prohíbe el paso de mercancías por el Tajo fuera de los términos de Toledo, Alarilla y Zorita. El asunto, dice Wright, era de interés gene$\mathrm{ral}^{39}$. Esto es cierto. Pero creo que hay una razón adicional práctica para presentarlo en romance. El mandato está fundamentado en disposiciones de las que no es seguro que en la cancillería quede constancia escrita: 1-4 «Sepades que yo fallé por pesquisa que mio avuelo mandó que nengún ganado ni otra cosa nenguna pora vender en razón de mercadura non passe Tajo en puente ni en barco fuera por la puente de Toledo e de Alfariella e de Zorita». Otra pesquisa prueba la obligación de dar portadgo los vecinos de Ocaña ${ }^{40}$. En otros documentos se insertan pesquisas que corresponden a la declaración de una o varias personas. La importancia de la pesquisa en los procesos judiciales es fundamental, y el afinamiento del proceso obligaría a habilitar un sistema de transcripción lo más fiel posible para trasladar al papel los testimonios orales. Así se ve en un documento de 1231, por el que Fernando III manda que los prados de La Lama se den al obispado de Burgos, que insertan dentro de la redacción latina del documento una pesquisa en romance ${ }^{41}$.

Como se ve, las motivaciones para el uso del romance fueron varias, como varios pudieron ser los ámbitos en los que se introdujo. F. J. Hernández ha destacado las conexiones entre la catedral de Toledo, la cancillería regia y el escritorio del que salieron las grandes obras jurídicas e historiográficas alfonsíes. Pero, según él mismo señala, la conexión entre catedral y cancillería venía de lejos.

${ }^{36}$ El documento fue publicado por Julio González, Reinado y diplomas de Fernando III; I Estudio, Córdoba, Monte de Piedad y Caja de Ahorros de Córdoba, 1980. II Diplomas (12171232), ibíd., 1983; III Diplomas (1233-1253), ibíd., 1986: vol. II, con el n. ${ }^{\circ} 670$.

${ }^{37}$ Edición en Francisco Javier Hernández, «Las cortes de Toledo de 1207», en Las cortes de Castilla y León en la Edad Media, I, Valladolid, Cortes de Castilla-León, págs. 221-263.

${ }^{38}$ AHN, Órdenes Militares, Cajón 86, n. ${ }^{\circ}$ 5; en el corpus Documentos españoles anteriores a 1700 es el n. ${ }^{\circ} 650$.

${ }^{39}$ El tratado de Cabreros, op. cit.

40 8-10 «Otrosí fallo por pesquisa que los de Ocaña de todo lo que passaren an a dar portadgo, fuera de pan e de vino e de sal que passen pora sus casas e pora sus ganados e non pora vender».

${ }^{41}$ Archivo Capitular de Burgos, 34, n. ${ }^{\circ} 2$. 


\section{Los documentos de la CATedral de Toledo (Y el ARChivo Munici-} PAL). LOS INICIOS DE UNA INVESTIGACIÓN

Mi interés por los documentos de Toledo data de hace bastantes años. Siempre me pareció que la importancia atribuida a Toledo en la historia del español no guardaba correspondencia con el estudio empírico de las fuentes documentales (especialmente presentes en archivos de la ciudad, pues el AHN tiene más bien la parte árabe) ${ }^{42}$. La primera intención fue incluir documentos de Toledo en un corpus financiado inicialmente por la Real Academia Españo$\mathrm{la}^{43}$. Ese objetivo se cumplió sólo muy parcialmente. Se incluyeron únicamente los documentos en papel del Archivo Municipal. De los pergaminos del AMT no se obtuvo reproducción a tiempo.

La investigación en estos archivos no fue cosa fácil. En el Municipal, el catálogo no describe piezas, sino documentos agrupados por épocas y contenidos. Los tres documentos romances más antiguos, de 1219, estaban en una carpeta bajo el rótulo genérico de «documentos latinos y árabes». Naturalmente, solo mirando pieza a pieza fue posible identificarlos. El documento original más antiguo del AMT es el privilegio por el que Alfonso VII el Emperador confirma el fuero a los francos de Toledo (24 de abril de 1136).

Más dificultosa fue la obtención del material del Archivo Capitular de Toledo (ACT). Al principio tuve que basarme en la impresionante obra Los cartularios de la catedral de Toledo de F. J. Hernández sobre los cartularios, que es sólo indirectamente un catálogo de los fondos del archivo, pues da referencias a los documentos sólo si éstos fueron copiados en los cartularios ${ }^{44}$. Después pude acceder al fichero manual del ACT y conseguí permiso para fotografíar una lista de 200 documentos (los más antiguos romances y algunos latinos) ${ }^{45}$.

\subsection{Presentación del corpus documental}

Los fondos del ACT han sido históricamente conocidos a través de los cartularios. Hernández divide éstos en dos grupos según su contenido. Un primer bloque lo compondrían los que tienen como tema la propiedad de la tierra (títulos de propiedad y derechos fiscales: compras, ventas y donaciones), y tam-

\footnotetext{
42 Menéndez Pidal no hizo referencias apenas a la documentación toledana en Orígenes del español (bien es cierto que casi toda queda fuera del período que trata).

43 Es el ya citado corpus de Documentos españoles anteriores a 1700, constituido por 1.500 documentos, la mayoría procedentes del Archivo Histórico Nacional.

44 Francisco Javier Hernández, Los cartularios de la Catedral de Toledo. Catálogo documental, Madrid, Fundación Ramón Areces, 1996, $2^{\text {a }}$ ed. (1 ${ }^{a}$ ed. 1985).

45 Para las publicaciones parciales de los fondos del ACT remito a la citada obra de Hernández.
} 
bién las ordenanzas o constituciones del cabildo de la catedral (534 documentos en total). El segundo grupo lo formarían los que contienen bulas sobre la primacía, en número de 167 (aunque el segundo, tercero y cuarto de los que se señalan a continuación también contengan algunas). Por su lengua (romance o latina escrita en la Península Ibérica) nos interesa el primer grupo, representado por cuatro códices: 1) Biblioteca Capitular de Toledo (en adelante, BCT) 4220, «Liber Privilegiorum», copiado en 1190; 2) AHN 996 B, «Liber Privilegiorum Ecclesiae Toletanae», del primer tercio del s. XIII; 3) AHN 987B, «Liver Privilegiorum Ecclesiae Toletanae», de hacia 1257; 4) BCT 42,23a, «Liber Privilegiorum Ecclesiae Toletanae», de hacia 1257.

Seguramente por comodidad, los historiadores han acudido a estos cartularios, mientras que las piezas orginales quedaban en su mayor parte inéditas. Aunque el valor de estos cartularios es innegable, sobre todo del primero, por estar confeccionado en fecha tan temprana, he preferido examinar la documentación original por un sano principio filológico (no obstante esto, me he servido de los cartularios para confirmar algunas lecturas). Huelga decir que los cambios son de todo orden, y no sólo en cuestiones gráficas de detalle (cambian los nombres de los lugares, como se ve en el doc. 1 de la obra de Hernández).

El documento más antiguo es la carta de dotación de la catedral de Santa María por Alfonso VI, dada en Toledo el 28 de diciembre de 1086 (original ACT O.2.N.1.1. ${ }^{46}$. Se ha de notar que, como es lógico, cabe hacer distingos en cuanto al «toledanismo» de los pergaminos del ACT. Algunos diplomas son de procedencia real, elaborados o no en Toledo. Entre los documentos propiamente toledanos se deben separar los que emanan del arzobispo (especialmente los de su «cancillería», que al parecer funcionó como tal al menos en la época de Jimenez de Rada, y es expresamente denominada así) y los elaborados por el cabildo o por alguno de sus miembros, es decir, por los clérigos que sirven en la catedral (como se verá, la diferencia entre unos y otros es importante). También hay que considerar documentos elaborados fuera de Toledo por clérigos de la catedral de Santa María, de manera segura en algunos casos y probable en otros.

Izquierdo Benito publicó los Privilegios reales otorgados a Toledo durante la Edad Media ${ }^{47}$, muchos de elllos en el Archivo Municipal. La fiabilidad filológica de esta obra es nula, pues lo mismo reproduce las deficientes ediciones de García-Gallo ${ }^{48}$, que toma el texto de confirmaciones posteriores que incluso

46 Francisco Javier Hernández, Los cartularios de Toledo, op. cit., págs. 5-8.

47 Ricardo Izquierdo Benito, Privilegios reales otorgados a Toledo durante la Edad Media (1101-1494), Toledo, Instituto Provincial de Investigaciones y Estudios Toledanos-Diputación Provincial de Toledo, 1990.

48 Alfonso García-Gallo, «Los fueros de Toledo», Anuario de Historia del Derecho Español, 45, 1975, págs. 341-488. 
romancean un texto originariamente emitido en latín. García Luján, en cambio, transcribe los diplomas catedralicios ${ }^{49}$.

Pero nos haríamos una idea errónea de los fondos del ACT, y más aún de la documentación toledana de los siglos XII y XIII, si omitiéramos el hecho de que una gran cantidad de piezas están en árabe, y provienen de las llamadas «escribanías mozárabes». El Archivo Histórico Nacional guarda cientos de documentos árabes, muchos de los cuales fueron estudiados y transcritos por González Palencia ${ }^{50}$.

Del enorme fondo de la catedral he seleccionado unos doscientos documentos que abarcan desde los orígenes hasta fines del s. XIII, y esto a pesar de que este estudio se circunscribe a un período más limitado, pues sólo de este modo era posible tener una perspectiva más amplia sobre el romance escrito en Toledo que incluyera el período alfonsí y la época de Sancho IV. También me he servido de algunos documentos del Archivo Municipal de Toledo, en particular de las tres cartas de compraventa de 1219 arriba mencionadas.

\subsection{Objetivos y método}

Mi propósito es el examen de la documentación toledana desde la época en que se empieza a escribir de una manera más o menos explícita el romance. El tramo cronológico elegido, 1171-1252, sólo en su fecha final obedece a un planteamiento previo. En otros lugares me he referido a cómo la llamada ortografía alfonsí se había configurado plenamente en la época inmediatamente anterior al reinado del rey Sabio (1252-1284) ${ }^{51}$. Esta investigación atiende al tiempo que precede a ese período, pero, naturalmente, habrá de medirse contra el fondo de los usos «alfonsíes». La fecha de inicio no obedece a restricciones previas, sino que fue acotándose a medida que examinaba las fuentes toledanas. De 1171 es el Fuero de Belinchón (ACT $1=$ A.10.E.5), el primer documento de nuestro corpus que presenta bastantes sintagmas en romance, aunque esto deberá matizarse (el ejemplar conservado es copia posterior). De 1171 son dos testamentos escritos en latín, pero que presentan algunas inserciones plenamente romances. Son ACT 202 (Z.4.A.8) y ACT 132 (0.3.A.2.2.).

Para el estudio de la documentación parto de una visión integral de la historia de la lengua y del documento. Resulta imprescindible situar los hechos lingüísticos en el marco de la historia general, de acuerdo con el principio de

\footnotetext{
49 José Antonio García Luján, Privilegios reales de la catedral de Toledo (1086-1482), Toledo, Torres, 1982, 2 vols.

50 Ángel González Palencia, Los mozárabes de Toledo en los siglos XII y XIII, 4 vols., Madrid, Instituto Valencia de Don Juan, 1926-1930.

51 Sobre todo en el art. cit. en n. 32. 
no contradicción. También es necesario averiguar en lo posible, el quién, dónde, cuándo y para qué de la elaboración de los textos. En un terreno más específicamente filológico, la autenticidad del documento debe de ser una preocupación constante, que obliga a examinar los aspectos «diplomáticos», sobre todo los llamados «elementos de validación», de entre los cuales los más conocidos son la rueda (privilegios rodados) y el crismón (privilegios, cartas plomadas, en su caso) y el sello. Atendiendo a las peculiaridades de nuestro corpus, dos son los que aparecen: el sello de cera «pendiente», generalmente el del arzobispo (acompañado a veces hasta de tres más) ${ }^{52}$ y las firmas de los actantes del acto jurídico y los testigos, entre las que veremos incluso la firma de puño y letra de Rodrigo Jiménez de Rada. Especial valor autentificador habrá de otorgarse a las firmas en árabe ${ }^{53}$. No menos valor otorgamos a la letra, así como a la credibilidad lingüística, para considerar auténtico el documento ${ }^{54}$.

En cuanto a los fines de la investigación, se pretende examinar el valor que para la historia de la escritura tienen los documentos toledanos. El nacimiento y desarrollo de la escritura romance está todavía por trazar de una manera completa, aunque contemos con trabajos valiosos, y éste pretende contribuir a hacer posible esa necesaria visión general. Habrá que verificar la relación y las posibles influencias entre diversos centros en los que escribir fue tarea corriente. Al respecto, el concepto de tradición de escritura resulta fundamental. El marco teórico-práctico de tal investigación viene definido por la triple correlación entre tipo y modo de letra (paleografía), usos gráficos (grafemática) y correspondencia fónica (fonética y fonología), según he expuesto en otro lugar ${ }^{55}$. La correspondencia entre usos gráficos y fonéticos no puede considerarse biunívoca, pues mientras los primeros son objetivables, los segundos son, en mu-

52 En la mayoría de los casos ha sido arrancado. Quedan, de todas formas, los agujeros característicos. Otras veces se conservan los «filos de seda a colores».

53 Los cartularios presentan también firmas imitiativas, al principio también las árabes (según señala Francisco Javier Hernández en la descripción de cada documento en Los cartularios de Toledo, op. cit.). Luego, se dará sólo una indicación sumaria: «et alia nomina arabica».

54 No se ha de creer que los docuentos originales no se equivocan nunca. En una carta plomada de Alfonso X, escrita el 8 de febrero por Álvar Pérez de Frómista (O.1.A.1.1.) vemos 1 cartarta por carta.

55 Cfr. mi comunicación citada en n. 32. Es necesario situar dentro de estos tres niveles los usos escritos, lo cual requiere prestar atención a las cambiantes relaciones entre ellos. En la cursiva del s. XV el empleo de non parece un hábito paleográfico al servicio de la identificación visual de las palabras, a la que contribuye la lineta. En la gótica libraria del s. XIII no puede deberse sólo a la paleografía, por lo que habrá que validar la distinción no-non al menos en la lectura del texto, lo que se confirma plenamente por el reparto contextual motivado por fonética sintáctica: non se empleó, p. ej. en Esc. I.I.6, ante $l$ y $n$ (no hay que olvidar que este adverbio soporta la enclisis del pronombre átono). No me parece, en cambio, que el latinismo sea una motivación para explicar la proliferación de non, salvo que se quiera entender latinismo como mera coincidencia con el latín. 
chos casos, variables o, si se quiere, «virtuales». Para trazar ese panorama el criterio expositivo es cronológico.

En otro lugar presentaré el examen del estudio lingüístico de los textos toledanos. Allí el punto de vista será el de la descripcion interna, adoptando una perspectiva en parte sincrónica y en parte histórica, que atiende a la identificación de los usos lingüísticos en los diferentes niveles (grafía, monética, morfología, sintaxis, léxico). Contra lo que suele ser habitual, considero la sintaxis clave para la valoración de la lengua, más allá del aspecto latino o romance que las terminaciones morfológicas confieren a las palabras. También es clave lo que podríamos llamar configuración discursiva del documento ${ }^{56}$, que tiene que ver con su mayor o menor libertad en la redacción, y cuya comparación en distintos documentos permite, al menos en teoría, trazar filiaciones entre escritorios.

Idealmente, se pretende identificar un estado de lengua, pero sin que necesariamente se prejuzgue uniforme en el lapso cronológico especificado. Antes al contrario, más bien cabe prever diferencias. Puesto que la reconstrucción de la lengua de uso a partir de los documentos sólo puede ser parcial por la naturaleza misma de la relación entre estos dos niveles, se atenderá sobre todo a la descripción del «sistema» que muestran los textos, entendiendo la oposición lengua hablada / escrita no como uno más de los parámetros por los que se manifiesta la variación inherente a la lengua, sino como el haz de relaciones fundamental que condiciona toda manifestación de la riqueza social y geográfica del idioma.

Como término de comparación nos servirá nuestro ya citado corpus Documentos españoles anteriores a $1700^{57}$. He preferido tomar como referencia este corpus por el conocimiento de los problemas históricos, filológicos y lingüísticos de cada documento, además de poder cotejar el facsímil. La comparación permite precisiones cronológicas imposibles de alcanzar de otro modo, debido a la falta de fiabilidad de las dataciones. Muchos filólogos desde Me-

56 Me aprovecho en esto de algunas ideas de Inés Fernández Ordóñez expuestas en «Tras la collatio o como establecer correctamente el error textual» (en Pedro Sánchez-Prieto Borja, coord., Propuestas para editar la literatura española (Edad Media y Renacimiento), «Critical cluster» de La Corónica. A Journal of Medieval Spanish Language and Literature, 30.2, 2002, págs. 105-80), allí aplicadas a las diferencias entre manuscritos de la Segunda Parte de la General estoria.

57 El grueso de los 1500 documentos hasta ahora transcrito se elaboró entre 1996 y 1998. Además de mi labor como coordinador, hay que señalar el trabajo de los siguientes investigadores: Cristina Castillo, Rocío Díaz, Carmen Fernández, Bautista Horcajada, José Manuel Lucía, Carlos Martín, Florentino Paredes y María Jesús Torrens. De cada documento se hizo una transcripción paleográfica, una presentación crítica y una reproducción facsimilar (para los criterios de transcripción y presentación, véase Pedro Sánchez-Prieto Borja, Cómo editar los textos medievales. Criterios para su presentación gráfica, Madrid, Arco/Libros, 1998). 
néndez Pidal, y casi todos los historiadores, no han tenido reparo en dar por originales copias posteriores.

Así planteado este estudio, por una parte pretende ser descriptivo (la documentación de Toledo presenta novedades llamativas para la historia de la lengua; las más visibles, en el léxico), pero por otra se pretende rastrear las conexiones de la escritura toledana con la de otros lugares, para lo que importa en gran medida situar la actividad escrituraria del arzobispado y del cabildo en el marco de la historia general de ambas instituciones, y en particular de sus integrantes. Como premisa, hay que otorgar prioridad a los aspectos internos (tipo de letra, grafías, valores fonéticos) para identificar esas posibles relaciones, aunque orientados por las vinculaciones humanas. Nótese que, por ejemplo, la procedencia regional o la formación en un centro determinado de un canciller no implica de por sí presencia de rasgos de escritura propios de esos lugares. El caso extremo, pero nada raro, es el de los cancilleres como Pedro de Cardona, oriundo de la diócesis de Vich, estudiante en Palencia, y canciller desde 1178, pero que, en palabras de Hernández, «jamás da señales de haber tocado un diploma regio» ${ }^{58}$. El caso citado más arriba sobre la posible controversia entre Diego García y el arzobispo Martín López de Pisuerga ilustra dos maneras de «tener» la cancillería.

\section{LA ESCRITURA ROMANCE EN LOS DOCUMENTOS DEL ARChivo CAPITULAR DE TOLEDO ENTRE 1171 Y 1152}

Por muchas razones, escribir en romance fue sentido como una necesidad que se verifica en todos los países románicos, pero no al unísono. Dentro del ámbito hispánico, tampoco todos los centros monásticos o catedralicios empezaron a escribir en lengua vernácula al mismo tiempo. Aunque todavía en esto hay que hacer distingos. Si entendemos por escritura romance la que emplea una ortografía con soluciones específicas para el romance (como sucede en los documentos de Fernando III y Alfonso X) está claro que en León ese uso empieza más tarde que en Castilla. Pero si valoramos la escritura por cómo se leía, desde luego el romance se escribía desde bastante antes, aunque no de una manera consistente y homogénea. Puede ser válida la observación al respecto de C. Pensado de que esos documentos que Menéndez Pidal consideró escritos en «latín arromanzado» se leían como romance (con el matiz importante de que no del todo) pero eran sentidos como latín ${ }^{59}$. Toledo, por las especiales circunstancias culturales, fue madrugadora en el «empleo consistente»

\footnotetext{
58 Francisco Javier Hernández, «Sobre los orígenes del español escrito», art. cit., págs. 141-142.

59 Carmen Pensado, «How was leonese vulgar latin read?», en Roger Wright, ed., Latin and the Romance Languages in the Early Middle Ages, London, Routledge, 1991, págs. 190-204.
} 
del romance, pero ese uso que aflora en 1191 en la carta puebla de Villa Algariva $\left(\right.$ ACT $173=$ Z.9.D.1.3. ${ }^{60}$ ) tiene una historia «subterránea» que es preciso reconstruir.

Aunque anterior al período en que se centra nuestra investigación, interesa como referencia para interpretar los inicios de la escritura romance un documento de Alfonso VII el Emperador de 4 de febrero de $1156^{61}$, escrito en Madrid. Según Hernández ${ }^{62}$ se trata de una copia del s. XII (a esto apunta, creo, el tipo de letra). En efecto, esta copia, sin sello pendiente ni trazas de haberlo tenido, presenta, a mi entender, algunos errores; así, 14 "cum data $m \tau$ zabiron", en lugar de 'et Abiron', quizá por leer dos veces el signo tironiano, la segunda como z. El error no pueden achacarse al notario Adrián ni al canciller Juan Fernández. El documento está escrito en un latín aceptable, con opciones léxicas que no obedecen todas a la presión del romance: 6 «facio cartam donacionis et textum firmitatis». El documento es una carta de donación a la iglesia de San Ginés de la villa de Salvanés, junto al Tajuña. No sabemos a qué iglesia se refiere exactamente. Hernández conjetura que se trate de la parroquia de la misma villa, y no de San Ginés de Toledo; como la catedral era la propietaria del lugar (por donación en 1099 de Alfonso VI) se explicaría, dice Hernández, que el documento se conserve en el Archivo Capitular (pero en realidad lo que hay allí es sólo la copia). Sea como fuere, el documento nada aclararía en su forma genuina sobre la extensión de las términos de Salvanés. Esto era lo habitual. Pero si este San Ginés fuera la parroquia toledana, entonces, la indefinición molestaría al arzobispo, que querría ver precisado hasta dónde se extendían los términos de Salvanés y qué «pechos» estaban obligados a dar sus habitantes a la sede primada. La copia, que creo coetánea del original de Alfonso VII, subsana esta deficiencia, y a ambos lados del signo, y tras la subscripción, se introduce una nota de deslinde del término. Desde luego, no es imposible que esa nota sea una falsificación, pero más probable parece que se hubiera añadido al diploma original o que sea traslado de otro diploma regio en el que se precisara el término de Salvanés (más bien esto segundo, pues lo apoya el cambio de perspectiva en la redacción: en el documento «ego Adefonsus... iussi»; en la nota «Imperatur Adefonsus exterminavit» ${ }^{63}$. Ésta es la parte inferior del documento:

\footnotetext{
${ }^{60}$ En lo que sigue damos junto a la signatura el número de orden del documento en mi corpus de la Catedral, ordenado cronológicamente.

${ }^{61}$ N. $^{\circ} 173$ = ACT Z.1.C.1.1.

${ }^{62}$ Los cartularios de Toledo, op. cit., n. ${ }^{\circ} 114$.

${ }^{63}$ El Fuero de Belinchón presenta, entre la lista de testigos, una línea que parece adición (¿en el original también?) y que justamente alude a los derechos del arzobispo (Hernández, Los cartularios de Toledo, op. cit., la transcribe entre paréntesis, quizá pensando en su carácter espurio).
} 


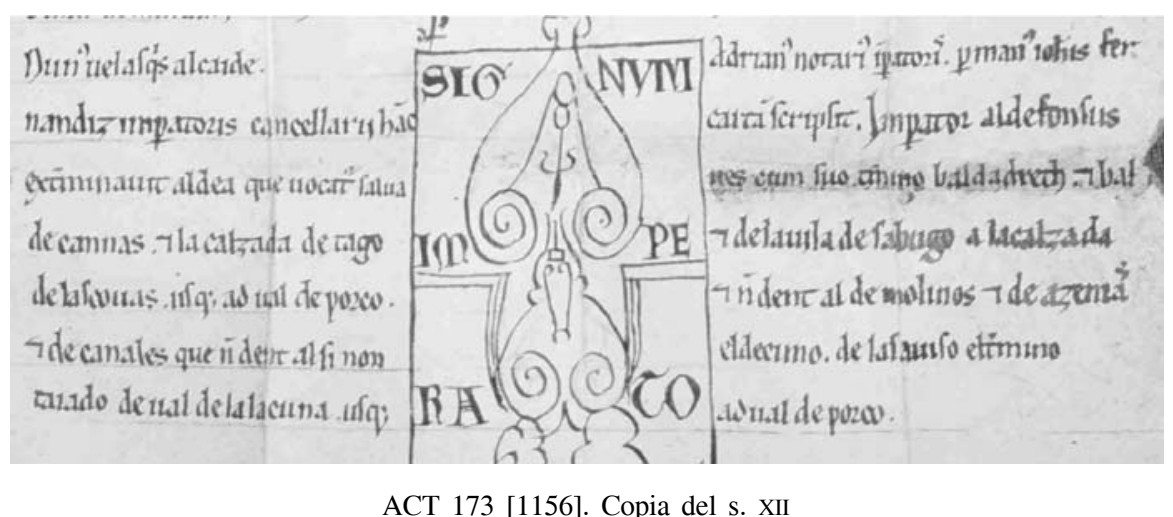

El interés lingüístico reside en que cuando se hace necesario precisar el término de la villa el romance aflora con bastante consistencia: «Imperator Aldefonsus / exterminavit aldea que uocatur saluanes cum suo termino baldadreth. $\tau$ bal/de cannas. $\tau$ la calzada de tago $\tau$ de la uila de sabugo $\tau$ la calzada / de lascouas usque ad ual de porco / $\tau$ non dent al de molinos $\tau$ de azenias / $\tau$ de canales que non dent al si non el decimo. delas aiuso eltermino / taiado de ual de la lacuna usque ad ual de porco». Aun cuando no se puede decir que el documento no muestre la presión sintáctica del romance, ésta es más evidente en la nota, incluso de los usos propios de la oralidad, como el empleo del que iterativo: «et non dent al... que non dent al». Las opciones léxicas son todas romances en la nota, pero lo más llamativo es el sistema gráfico, plenamente avanzado, y disonante de los usos latinos del documento: calzada, aiuso, taiado. Como vemos, fue la necesidad de precisar los límites la que aconsejó introducir un segmento que entendemos como inequívocamente romance (salvo usque, elemento propio de la lengua jurídica), por lo que el documento, con la adición de esta nota, seguramente coetánea de Alfonso VII, recorre toda la gama que va del latín al romance, con una lengua completamente divergente de la vernácula en el introito ( 1 «inter cetera [...] $\tau$ misericordie opera helemosina maxime comendatur qui ait [...]»), y con segmentos de apariencia latina pero en los que se percibe la plantilla sintáctica romance ( $\tau \tau$ iacet inter taguniam $\tau$ tagum. $\tau$ dono $\tau$ concedo uobis ipsam aldeam»). Ciertamente, quienes redactaron en 1156 este documento no eran ajenos a los avances en la mejora del latín ${ }^{64}$.

64 Aun cuando la copia pudo modificar algunos topónimos, nótese el intento de sustraerse a las formas romances en 7 Taguniam, Tagum, donde leerían [g] y no la prepalatal sonora, mientras que $i$ en 9 in Maieride apunta a una pronunciación palatalizada de lo que otras veces escribían con $g$ (pero recordamos que la lectura no tenía por qué ser unitaria; pudo ser este el caso de azenias (en la nota), leído como -nj- o con palatal nasal. Por el contrario, cuando por falta de tradición no se 
4.1. Sin duda del escritorio de la catedral es el testamento de Domingo Pérez, que en abril de 1171 dona al cabildo una parte de sus bienes ${ }^{65}$. Como la mayoría de los testamentos toledanos no lleva sello, pero las firmas originales sirven de autentificación; entre ellas, en árabe, la de «Juanes b. Ayub», según Hernández ${ }^{66}$. La letra de las firmas es más parecida que la del texto al tipo de escritura de códices; su interés para la paleografía radica en que demuestra la coexistencia entre varios tipos de letra, pero aquí no en función, como estamos acostumbrados a ver, de la clase de texto, sino en sentido social, según el grado de instrucción ${ }^{67}$. El presbítero Forto (22), notario según Hernández, tiene buena letra gótica, aunque no angulosa (22). En cambio Juan el sacristán (26) tiene una letra insegura.

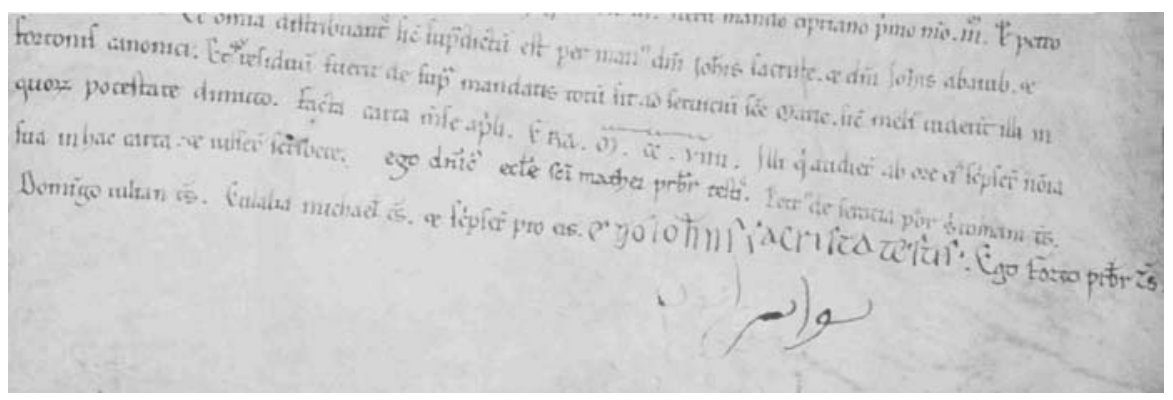

ACT $202(1171)$

El texto, en latín, presenta el incipit habitual: 1 «Domincus Petri infirmus corpore sed sana mente facio testamentum de omnibus que possideo...». En el cuerpo del documento se manifiesta claramente lo que Hernández llama «plantilla romance»; la intención de transmitir con claridad un contenido que importa apenas permitiría otra cosa; desde luego, no parece mejor este latín que el del documento de Alfonso VII. La alusión a que los testigos oyen la carta obliga a preguntarse cómo sería esa lectura: 20 «illi qui audierunt ab ore eius scripserunt nomina sua in hac carta aut iusserunt scribere». No creo posible una lectura romance (pero aquí no se dice que se leyera, sólo se alude a la

ve medio de «latinizar» la forma vernácula se introduce con «qui vocatur» («aldea qui vocatur Salvanes», que se repite en la nota, lo que tal vez es indicio de autenticidad de ésta). Ello apunta ya en esta época a una clara conciencia de la distinción entre latín y romance. Una variante es, en el diploma de donación de Alcalá a la iglesia de Toledo por Alfonso el Emperador (A.3.A.1.1., de 1129), 5 «de castro quod nunc dicitur Alcala, antiquitus vero Complutum».

65 N. 202 = ACT Z.4.A.8.

66 Los cartularios de Toledo, op. cit., n. ${ }^{\circ} 158$

67 No puede, con todo, la calidad de la letra tomarse como índice seguro del nivel cultural (recuérdese del Libro de buen amor 18b «en fea letra está saber de gran dotor», aunque es posible que el verso de Juan Ruiz se refiera a la mala letra de copias que difunden contenidos valiosos). 
audición de los contenidos). No ha de extrañar que el léxico romance aflore en aposición a la onomástica personal: 17 «Cipriano primo meo» (nótese la opción frente a cormano), 12 «Johan Sarrano, pastor» y especialmente 4 «Dominico mozarau». Desde luego, no hay intento de latinización de Seragosa (en 3 «Petro de Seragosa»). Rompen el aspecto latino del documento formas romances, no sólo palabras citadas o nombres propios, sino nombres comunes: 13 collazo, 12 cordero o 14 porcas parideras, donde sería posible leer tanto [ó] como [wé], mientras que la pronunciación romance (coetánea o anterior) se refleja en 10 iermano. El arabismo 13 fanega muestra adaptación al sistema gráfico general, y apunta tal vez a lectura generalmente aspirada de la $f$ - La conexión con la tradición de escritura latina es evidente en 7 Macheda con ch, pero el uso también se aprecia en textos romances vincualdos a Toledo, como el Auto de los Reyes Magos y el Fuero de Alcalá (más adelante me refiero a la geografía de $c h$ con valor $/ \mathrm{k} /$ ).

Del mismo año que el anterior es la carta partida por abc que reparte el término de Azaña entre el cabildo de la catedral y el conde Ponce de Minerva, en diploma original ${ }^{68}$. A una autoría mozárabe apunta la firma en caracteres árabes de «Fernand b. Hasan que escribió» ${ }^{69}$. Se ha de notar, sin embargo, que muchos cristianos provenientes de diversos lugares arabizaron sus nombres, y ni siquiera los francos son ajenos a este proceso de «mozarabización». Es el caso de «Yahya ben Teman», que comparece como testigo en un documento de 1182, en el que el escribano se sintió obligado a precisar al pie en árabe «es gascón del arrabal» ${ }^{70}$ (p. 140). Nada de particular tiene en sus usos paleográficos ni textuales esta carta. La letra es mucho más cuidada que la de ACT 202, y de astas más alargadas. Quizá su latín puede calificarse como mejor que el de otros documentos. Así usa el demostrativo is (2 «eandem aldeam» y no «illam aldeam»), en un sintagma en el que incluso se latiniza morfológicamente el arabismo. Esto interesa mucho, porque a mejor latín menos comprensión $\mathrm{y}$, por tanto, más necesidad de romance (también internamente en el mismo documento). La escritura romance nace por contraste; al mejorar el latín los segmentos en estilo vulgar destacan. Pero es la sintaxis la que perfila mejor la presión del romance: «supra fontem que vadit usque ad terminum de Font Alba», aunque el juicio negativo ha de ser matizado por el correcto acoplamiento de preposición y caso: 6 «a termino de Font Alba usque ad terminum de Hylesques ${ }^{71}{ }^{\gg}$. La lectura por letras ha de ponerse en duda, por lo menos

${ }^{68} \mathrm{~N}^{\circ}{ }^{\circ} 132=$ ACT 0.3.A.2.2.

${ }^{69}$ Los cartularios de Toledo, op. cit., n. ${ }^{\circ} 159$.

70 Ángel González Palencia, Los mozárabes de Toledo en los siglos XII y XIII, 4 vols., Madrid, Instituto Valencia de Don Juan, 1926-1930: Volumen Preliminar, pág. 140.

$71 \mathrm{O}$ «hylesquas» 'Illescas'. 
parcialmente. Se marcan algunas asibilaciones: 2 conveniencia, particiones. La forma 5-7 Pantola del topónimo Pantoja puede ser intento de latinización, si $l$ no sonaba palatal lateral. Resulta rara la forma 8 aga (no parece que pueda leerse contra ni circa) en 8 «aliud pratum remansit aga (?) Ocner».

Uno de los documentos más antiguos con segmentos de cierta entidad en romance podría ser el Fuero de Belinchón $(1=\text { A.10.E.5 })^{72}$, otorgado por el arzobispo Don Cerebruno en 1171: «Facta fuit cartam in era $\mathrm{M}^{\mathrm{a}} \mathrm{CC}^{\mathrm{a}} \mathrm{VIIII»}$. El documento fue tal vez redactado por el abad Domingo Blasco, Juan Miguel de Belisca y Domingo Miguel de Ayllín («Et isti sunt qui fecerunt cartam»). No sabemos quiénes eran estos personajes. Hernández no cree que sean del escritorio episcopal. No estoy tan seguro. En cualquier caso, es probable que partieran de un modelo previo. Inaugura la tradición foral de los arzobispos toledanos, bajo forma de las cartas-pueblas, mal llamadas fueros breves (puede compararse el inicio de la carta-puebla de Villa Algariva, de 1191 y del Fuero de Alcalá). El escribano del documento original fue Fortún: «Fortunius scripsit cartam» (según Hernández no parece que sea el conocido Forto, que figura en tantos diplomas de la catedral). Un «dompnus Fortunus sacerdos Sancte Matie» es testigo de la donación en febrero de 1213 de unas casas y viñas en Madrid a la Catedral de Toledo $^{73}$ (bien es verdad que hasta esa fecha median 42 años). El ejemplar conservado no tiene sello ni firmas autógrafas; es claramente una copia de hacia 1200 (Hernández cree que la copia es poco anterior al otorgamiento de un segundo fuero a Belinchón, el 20 de junio de 1198). La pieza es de calidad aceptable; tiene pautado, pero aun así muestra cierta irregularidad, de copia hecha no con grande esmero. La letra es parecida a la de códices, menos estilizada que la de los diplomas, con astiles poco prolongados. No tiene ni de lejos la perfección de letra de ACT 73 (1175). Y es que en el escritorio de la catedral coexistían usos paleográficos muy distintos.

En la situación que muestra el ejemplar conservado del Fuero de Belinchón, la inserción del romance parece comparable a la del Fuero de Madrid, de hacia 1200. El grado de romanceamiento corresponde aparentemente más a 1200 que a 1171, pero hay que tener presente que los usos romances no se manifiestan al mismo tiempo en todas partes. La observación de Lapesa acerca de latín y romance en el Fuero de Madrid parece aplicable al de Belinchón: conviven sintagmas latinos y sintagmas romances ${ }^{74}$. El incipit está en latín re-

\footnotetext{
72 Publicado íntegro por Juan Francisco Rivera Recio, La Iglesia de Toledo en el siglo XII (1086-1208), Roma, Instituto Español de Historia Eclesiástica, 1966-76, vol. II, págs. 102-106 (con alguna deficiencia que nota Hernández en Los cartularios de Toledo..., op. cit., n. ${ }^{\circ}$ 160) y parcialmente por Menéndez Pidal (Crestomatía..., op. cit., vol. I).

73 AHN, Clero, carpeta 3018, n. ${ }^{\circ} 14$.

${ }^{74}$ En El Fuero de Madrid, Madrid, Publicaciones del Archivo de la Villa, 1932 (trabajo recogido en Rafael Lapesa, Estudios de historia lingüística, Madrid, Paraninfo, 1985, págs. 157-166).
} 
lativamente correcto (entre las opciones léxicas de este latín; p. ej. plasmavit, verbo que encuentro en la Fazienda de Ultramar y en la Vulgata (Isaías 37:26). El uso solemne (a7 «facio paginam testamenti») deja paso a la forma foro, sin diptongo explícito. La tradición de escritura latina representada muestra algún grado de corrección más en lo léxico que en lo sintáctico: a3 «triunphator de oste» (por el carácter de copia no haremos cuestión del empleo o no de $h$-; véase a8 abitantes, pero a7 honor). Las opciones latinas son frecuentes: a9-10 «in primis aiat».

La grafía muestra variaciones duraderas, como a13 cavaleros y cavallo (también Belinchon $\sim$ Bellinchon). Hay representación del diptongo procedente de $\mathrm{E}$ breve tónica (b19 bierten), pero no de $\mathrm{O}$ (no tiene obviamente este origen quomodo, pero luego se insertó en la variación o ue). Esta situación coincide con la que muestran escrituras leonesas del s. XIII (y posteriores), y también con la del Fuero de Alcalá, otorgado hacia 1235 por Don Rodrigo Jiménez de Rada. Al faltar $c$, la $z$ asume su valor ante $a, o, u$ : b18 cabeza, infanzones. Se intercambian $c$ y $z$ en fazer facer (así sucede todavía en el Fuero de Alcalá). Entre las grafías consonánticas, llaman la atención dos rasgos, sobre todo el primero, por su uso toledano: ch en chasa (una vez, frente a mayoría de casa) y $k$ para el mismo valor en a14 karneros. Hay amplia representación de las prepalatales en la forma que se estabilizó en el llamado castellano alfonsí: moiones, Taio. La unidad para el uso del código latino o romance es la frase, y otras veces el sintagma como en a29 «mauro qui dederint a captivo», donde es obvia la motivación para la presencia de $a u$ (desde luego, no es manifestación de pervivencia en lo oral del diptongo). La fonética romance se muestra con nitidez en un sinfín de palabras: ganado, mancebos, manneria, coto, aiuso, tornadizo, iuveros, fazendera, al tiempo que son muestra muchas de ellas de la institucionalización del léxico foral (a23 merino, a23 montadgo, a24 portadgo). Para la $n i$ de calonia vale lo dicho arriba sobre azenia. Desde luego, no hay representación isomórfica del romance: a19 pecto 'pecho', puede interpretarse como variación gráfica ( $c t$ como forma de escribir [ĉ]) o por su adscripción léxica al latín). Y habrá que preguntarse si esto es mero dimorfismo gráfico o es dimorfismo lingüístico. La variación también afecta al léxico, como se ve en a18 casa frente a 21 domus o b21 «contra sarrazenos» ('hacia la frontera') b29 «in frontera paganorum». La proximidad, sobre todo en la primera pareja, demuestra que la alteridad latino-romance está condicionada también por la variatio (sin descartar razones intratextuales como la formación textual en sucesivas fases, lo que se percibe con nitidez en fueros extensos como el de Alcalá) ${ }^{75}$.

75 Para la variación interna en un texto romance, cfr. Margherita Morreale, «Trascendencia de la variatio para el estudio de la grafía, fonética, morfología y sintaxis de un texto medieval, ejemplificada en el MS Esc. I.I.6», Annali della Facoltà di Lettere e Filosofia dell'Università di Padova, II, 1978, págs. 249-261. 
Esa variación léxica romance aflora también por encima de las peculiaridades ortográficas: a32 poplatores vs. abitantes, que en el contexto histórico parecen sinónimos. El verbo adopta la forma romance, salvo por la marca - $t$ en descavalget, que puede compararse con quintent, donde -nt es mera marca morfológica (v. faciant) o mero indicio de que $-t$ valía aquí $[\varnothing]^{76}$.

Trasparenta la oralidad el arabismo sintáctico «tres tres»: a14 «pectent tres tres solidos aut tres tres karneros» (v. i. 5.3.), lo mismo que el empleo adverbial separativo de preposición y adverbio (a19ss. «illos homines [...] del archiepiscopus aiuso», o el puramente adverbial $\mathrm{b}$ «Taio aiuso»). Son de matriz romance las descripciones topológicas: b18 «la Cabeza Gorda inter Bellinchon et Tarancon» ${ }^{77}$ (los topónimos no muestran intento de latinización: b23 Madrid). También las especificaciones legales: a50 «et ganados de alteras terras qui in montes de Bellinchon steterint», pero téngase en cuenta la especificidad latina de las formas verbales, lo que parece ser una constante frente a los sustantivos (v. q. b1-2 «habeant suo medianedo», a46 «tornadizos tornaverint»). Pero la tradición foral está ya constituida, lo que es un freno parcial a la unidad de código, y sólo ésta explica su pervivencia luego en los fueros de 1230-1240: «et octavo ad palacio et exeat homiziero», b37 «alia fazendera non faciant» ${ }^{78}$. Cuando el sintagma incluye nombre (en este caso adjetivo) específicamente latino su pervivencia histórica fue menor: a47 «mauros genuos».

Conclusión obvia del breve acercamiento al Fuero de Belinchón es la dificultad de valoración cronológica de sus usos, pues no creo que la fidelidad hacia el ejemplar de 1171 fuera absoluta. Lo seguro es tomar los rasgos que muestra como propios de la escritura de finales del siglo XII, sin descartar que muchas formas inequívocamente romances estaban ya en el documento original ${ }^{79}$. Muchos de estos usos no fueron «aprovechados» por la ortografía cancilleresa de Fernando III (chasa, karneros), pero el castellanismo gráfico-fonético es evidente.

4.2. De 1163 es el testamento del alguacil mayor de Toledo, el mozárabe don Illán Pérez, por el que deja dos viñas a la catedral. La carta latina, magis-

\footnotetext{
${ }^{76}$ Cfr. -nt luego en el Poema de Mio Cid, que ni es marca de escritura antigua de la terminación verbal ni mera ultracorrección, según explica Fernando González Ollé en «Cuestiones cidianas: 1. La falsa terminación -NT de algunas terceras personas de plural y otros puntos de mofolología verbal. -2. Casadas 'servidoras'», Actas del Congreso Internacional. El Cid. Poema e Historia, Burgos, Ayuntamiento de Burgos, 2000, págs. 129-150.

77 B19 «quomodo las aguas bierten de faz a Bellinchon al uado d'Almunia».

${ }_{78}^{78}$ Los dos segmentos están en el Fuero de Alcalá.

${ }^{79}$ Francisco Javier Hernández («Sobre los orígenes...», art. cit., pág. 149) lo compara con el de Valfermoso de la Monjas, de 1189, editado por Rafael Lapesa («El fuero de Valfermoso de las Monjas», Homenaje a Álvaro Galmés de Fuentes, 3 vols., Madrid, Gredos-Universidad de Oviedo, I, págs. 43-98.
} 
tralmente comentada por Hernández ${ }^{80}$, muestra la inserción en un latín con alto grado de corrección de sintagmas romances que identifican las propiedades («ab oriente maiolo del cormáno. Ab occidente: maiolo de Antonino»), con la extraordinaria peculiaridad de que se introducen acentos (Cormáno, albór, $\mathrm{Pe}$ pín) La calidad lingüística parece ir acorde con la letra, para Hernández «carolina caligráfica de transición, elegantemente alargada», parecida a la de un sacramentario de la Biblioteca Capitular.

De gran calidad formal es también el documento por el que Pedro Alguazil da un horno a la catedral ${ }^{81}$. La letra confirma la coexistencia en Toledo de la escritura de cuerpos pequeños y astiles prolongados, que luego será utilizada en los diplomas regios más solemnes, y la de astas que apenas sobresalen por encima del cuerpo de las letras redondas, que será propia de los códices alfonsíes tras una evolución y afinamiento que sólo se había alcanzado poco antes de mediar el s. XIII, pero que de momento se emplea en formas más toscas todavía en los diplomas.

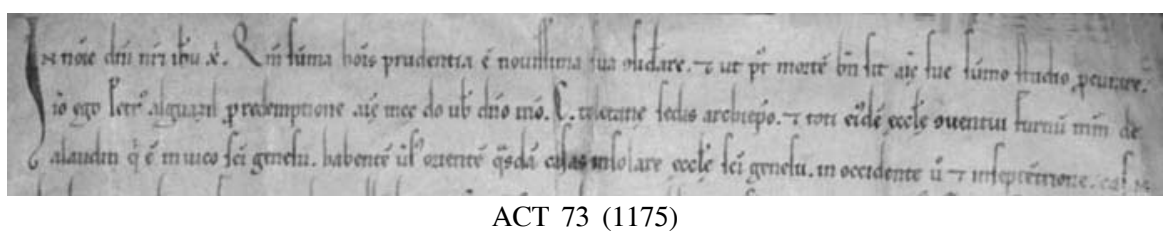

Hernández compara este documento con otro inmediatamente anterior por el que Alfonso VIII concede el mismo horno a Pedro Alguazil (E.8.A.1.1.), y destaca cómo el cotejo de la lengua es muy favorable al documento catedralicio. Lleva razón, y los segmentos que contrapone son contundentes («quasdam casas» frente a «unas casas»; «quae fuit uxor hermilii Bovini» y no «muliere de Ermildo Bovino» de la cancillería). La versión de la catedral parece situarse en un extremo de los códigos de escritura que ya empezaban a coexistir, con intromisiones del romance aparentemente limitadas a la onomástica («Petrus Aluazil»; «furnum meum de Alaudin»). La sintaxis reformada se manifiesta mejor en el protocolo: «quomodo summa hominis prudentia in novissimi», donde subrayo elementos del mismo sintagama que se separan de acuerdo con un empleo inusual hasta avanzado el s. XII ${ }^{82}$. Pero cuando se llega a lo que interesa la sintaxis se torna más llana: «furnum meum de Alaudin qui est in vico Sancti Genesii», frente al documento de la cancillería: «unum furnum de Alauaidin in barrio Sancti Genesii situm», y ni siquiera vicus por barrio al-

\footnotetext{
${ }^{80}$ «Sobre los orígenes...», art. cit., pág. 147. El documento lleva la signatura A.3.A.1.1.

${ }^{81}$ ACT 73 = E.8.A.1.6.

82 Cfr. Ángel López García, Cómo surgió el español, op. cit.
} 
canza a enmascarar la necesidad de transparencia ${ }^{83}$, para volver luego al convencionalismo formulario en las admoniciones: «Ut ammodo nec ego nec aliquis de genere meo vel alieno...». No estamos tan lejos de la alteridad de código dentro del mismo documento, cierto que no tan radical como en otros casos. Desde luego, el escribano catedralicio tiene a la vista el documento de la cancillería, aunque arregle su latín. Nótese que el protocolo inicial estaba ya en el documento de la cancillería ${ }^{84}$. Otros rasgos como el empleo de $e$ caudata y del ae ultracorrecto en aeclessiae no creo que puedan valorarse como «resonancias clasicistas», según hace Hernández, sino como meras convenciones ortográficas que tiempo antes muestran escrituras de diversos centros (aecclessiae está en el diploma real de 1143 arriba citado).

En la década de 1170 los documentos latinos toledanos presentan las intromisiones típicas del romance en los nombre de lugar o de persona (de origen latino o árabe), pero también en el elemento adyacente del topónimo. Es el caso de ACT 176 ${ }^{85}$ : «in pago de Azuqueca». La mujer del alcalde de Toledo, María, hija de Pelayo Pérez de Frómista, devuelve una viña al arzobispo y le perdona el dinero prestado sobre ellas. No se dice el copista. Hay varias firmas originales en «latín» y en árabe, pero en árabe lleva una curiosa suscripción: «Jálid b. Solaimán b. Gasan b. Servando oyó que el arzobispo dijo lo anterior en romance, y Domingo Salwat también» ${ }^{86}$. Esta práctica fue típica de las escribanías mozárabes. No parece, sin embargo, que ni el tipo de letra ni la redacción indiquen que esta pieza proceda de una de estas escribanías. La nota resulta del máximo interés para entender el problema de la lectura de los textos. Para esta manera de «decir» los documentos, la inserción de palabras romances era clave, así como el empleo de una sintaxis de matriz romance en los segmentos que concentran la información relevante.

No de otro modo son las cosas en ACT 2 de $1179^{87}$, carta otorgada por el prior de San Servando, de quien no sabemos si tenía oficio en la catedral. Está escrita por un tal Erato en letra más próxima a la de códices, y aunque no mala, menos estilizada. Una frase revela lo esencial del contenido: 2-3 «do et concedo tibi Gómez et uxori tue Marie Pelaiz unam albor in Azukeca que nominatur Cossulus».

${ }^{83}$ Para VICUS y su posible vigencia en romance, Cfr. un documento de Alfonso X de Galicia «E a la otra mano en vega de Peyçaes onze talegas, e la meatad del vico de Carralcova fata el comaro d'Alvar como se departe de la heredat de los caualleros». Vicos aparece fijado como topónimo en Documentos españoles anteriores a 1700, n. 1082 (cerca de Jerez).

${ }^{84} \mathrm{El}$ documento de la cancillería puede verse en Julio González, El reino de Castilla en la época de Alfonso VIII, Madrid, CSIC, 1960, 3 vols., doc. n. 938.

85 V.11.B.1.19.

${ }^{86}$ Francisco Javier Hernández, Los cartularios de Toledo, op. cit., n. ${ }^{\circ} 185$.

87 A.10.B.2.2. 
El documento de 1184 por el que Alfonso VIII confirma sus privilegios a la catedral de Toledo ${ }^{88}$ presenta un latín relativamente avanzado, por lo que el contraste resulta abrupto, no ya con los topónimos, especialmente menores (10 Ranconada de Perales, 7 Zalencas, 10 Salvanés, 15 Alcavón), pues los más conocidos y tradicionales se intentan latinizar (de Magerito, apud Agretam), sino con sintagmas tan llamativos como 12 «privilegium de alferezias», donde el léxico romance (en este caso bajo la forma del arabismo) aflora con nitidez por motivaciones obvias (el rey quiere dejar claro el derecho confirmado). No nos sorprende mucho, pues quien escribe tenía pericia suficiente para ello. Es el anciano «Magister Geraldus», notario ya con Alfonso el Emperador, que escribió, probablemente la nota romance del diploma de $1156^{89}$. La letra es de gran calidad, pero no muestra el grado de estilización que se hará característico de los diplomas regios y que sí se percibe en el documento catedralicio de 1175 antes comentado (ACT 73), y ello es de por sí un síntoma de discontinuidad en los usos cancillerescos, o, si se quiere de renovación. Pero quienes participaron en este documento estaban familiarizados con una manera de escribir «consistentemente romance». Si no, no se entiende la facilidad con que el notario se mueve entre los dos códigos.

4.3. Pero más significativa es la carta-puebla de Villa Algariva, de $1191{ }^{90}$. Fue publicada parcialmente por Menéndez Pidal, y ahora Wright y Hernández destacan su importancia, el primero al considerarla el documento más antiguo escrito en una ortografía plenamente romance; el segundo, al creerla resultado de una escribanía mozárabe y de una manera de escribir ideada en Toledo. Otorgar a un documento la prioridad de la escritura romance (aunque la entendamos aquí restringida a los reinos de Castilla y León) es pisar terreno resbaladizo, pues dependerá de a qué tipo de escritura nos queramos referir. Desde luego, si por tal entendemos la que se configurará como oficial en Castilla bajo Fernando III, esta carta-puebla dista de estar en esa línea (tampoco lo están las Paces de Cabreros: fillo, mulleres, morancia se apartan de los usos castellanos). Pero tampoco es cierto que sea la primera en sentido absoluto. Por citar sólo documentos que he podido consultar directamente, señalaré uno del monasterio de Santa María de Aguilar de Campoo ${ }^{91}$, de 1174, que rubrica un acuerdo entre la iglesia de San Miguel de Cohorcos y el monasterio de Santa María de Aguilar:

\footnotetext{
${ }^{88}$ N. ${ }^{\circ} 111$, ACT I.12.A.1.4.

89 «Magister Geraldus regis notarius, Guterio Roderici existente cancellario, scripsit».

90 ACT Z.9.D.1.2a.

${ }^{91} \mathrm{AHN}$, Clero, Palencia, Carpeta 1648, N. 5 (hace el número 207 en nuestro corpus Documentos españoles anteriores a 1700).
} 
(1) In dei nomine Amen. Notum sit tam presentibus quam ffuturis. Quod concilio de Conforcos. Et el abat de sancta maria (2) de aguilar. ouieron tal vida en vno. che la eglesia de sancto michael. $\tau$ la eglesia de sancta maria es vna collacion $\tau$ los ffijos (3) dela eglesia ffacen sennas rraçiones. $\tau$ los ffrayres sacan como vno delos. Et si por auentura non ouiere hi filjo (4) dela villa. che canten los ffrayres amas las ecclesias. \& tomen todo. Et otrosi silos ffrayres non podieren seruir (5) las ecclesias $\tau$ ffijos ouiere hi dela ecclesia. siruan las ecclesias. $\tau$ tomen todo. $\tau$ sobre esto cunpliendo los ffijos delas (6) ecclesias. $\tau$ los ffrayres. njngun omne non aya poder de meter capellano de ffora. jsti ssunt testes. Dominjco an(7)dres. don bartholome don gomez martin dominjco martin pelaz. ferrant martin. Et concilio de confortos (8) testes facta carta Sub era. mill. cc. xij:

No es testimonio aislado. De 1186 es esta carta de compra-venta también rubricada en Santa María de Aguilar ${ }^{92}$.

(1) In dei nomine. Ego peidro martinez \& lop diaz $\tau$ ferranroiz. $\tau$ ordon martinez uendemos auos abbat don sancho martinez de aguilar. $\tau$ uestros (2) fratres. el monesterio de sanct caluador. de enestares de campo. cum toda sua hereditad. $\tau$ hel palacio de ferran garciaz (3) la pelega cum toda sua hereditad. $\tau$ hel solar de ranola ke fue de feran garciaz la pelega con los molinos $\tau$ con toda (4) sua hereditad \& hen menaza un solar con toda sua heredad. $\tau$ la heredat de pozacos. $\tau$ de menaza asta en somo conia. (5) quanto nos de uemos heredar uendemos $\tau$ robramos toda questa heredad. por c. $\tau$ sesaenta morauedis. $\tau$ si (entre renglones) algun om(6)bre hesta carta quisiere crebantar con iudas traditor haia part $\tau$ en coto regi (entre renglones) mil morauedis pectet. $\tau$ tal heredat $\tau$ en (7) tal logar. Facta carta sub. era millesima. ducentesima. uicesima. quarta. Regnante rex aldefonsu. cum regina (8) alienor en toleto $\tau$ en castella. Roj gutierez maior domus regis.

Y seguramente podrán añadirse más, quizá de otros lugares. De tierras sorianas, y de hacia 1156, es la infeudación del castillo de Alcozar, que publicó Á. Canellas López ${ }^{93}$.

Los dos documentos palentinos muestran una manera de escribir tan «consistentemente romance» como la de la carta-puebla de 1191. Menéndez Pidal afirmó que esta carta-puebla era del notario de D. Pedro Alpollechén, producto pues de un ambiente cultural idéntico al de las escribanías mozárabes de la ciudad. Hernández sugiere que fuera una de esas escribanías la que expidiera el documento. Y explica este investigador de manera muy sugestiva cómo las escribanías mozárabes idearon una manera de escribir romance más apropiada y precisa que la de quienes en León usaban la vieja escritura (que no lengua) la-

${ }_{92}$ AHN, Clero, Palencia, carpeta 1648, n. ${ }^{\circ} 19$ (209 en nuestro corpus Documentos españoles anteriores a 1700).

93 Ángel Canellas López, «Un documento soriano romanceado: infeudación del castillo de Alcozar hacia 1156», Homenaje a Francisco Ynduráin, Zaragoza, 1972, págs. 107-117. Y Cfr. de Juan Antonio Frago Gracia, «El paso del romance a la escritura...», art. cit., págs. 94-95. 
tina arromanzada. Para este autor, fueron mozárabes los autores de los primeros documentos «consistentemente en romance que aparecen en el reino de Castilla». No veo que sea así, por más que estos documentos palentinos que he aducido estén en la frontera castellano-leonesa. Una cosa puede afirmarse. La carta-puebla de Villa Algariva manifiesta una clara dependencia de maneras de escribir propias de escritorios de la submeseta norte, pero sin que pueda darse una precisión local absoluta. Nada más lógico debido al carácter esencialmente mestizo de las tradiciones de escritura... aun con ciertas líneas locales que se manifiestan con más constancia en el recogimiento de los monasterios, mientras que las catedrales muestran muchísima más variación. Ni siquiera con Alfonso $\mathrm{X}$ puede hablarse de uniformidad, entre otras cosas porque ésta no se pretendía (véase lo observado arriba acerca de la variatio). En cuanto a los rasgos de lengua, Menéndez Pidal consideró algunos de éstos como mozarabismos, pero sugirió que igualmente podían interpretarse como leoneses. Esto segundo es cierto. A tradiciones leonesas no occidentales, sino centrales, orientales y de transisición con Castilla corresponden varios usos gráfico-fonéticos de la carta. Y más allá del foneticismo de $k e$ frente a que puesto de relieve por Hernández (ke, akella), puede rastrearse su empleo en diversos escritorios leoneses y castellanos (pero también aragoneses). En realidad, el uso más extendido fue el de $k a$, especialmente fijado en karta y en la abreviatura de kalendas, donde llega hasta el fin de la Edad Media, mientras que el de ke (especialmente para la conjunción que) es bastante más limitado. Lo encontramos precisamente en el segundo de los documentos palentinos, y más que un genial hallazgo ortográfico al servicio del foneticismo es muestra de los tanteos (y de la variación, en su caso) entre diversas posibilidades. Naturalmente, el uso no sale de la nada, sino que es transferencia de un empleo que halló cierto acomodo en tradiciones visigóticas de escritura (y que manifiesta el códice emilianese 70 de la RAH, entre otros muchos) ${ }^{94}$. En el Monasterio de Oña estaba muy arraigada esta grafía, al menos todavía en la segunda mitad del s. XIII (según compruebo en un rápido muestreo en nuestro corpus documental). La manifestación de $i e$ frente a $o$ de la carta-puebla tiene paralelo en tantos documentos leoneses (y algunos menos castellanos), y su cumo nos recuerda sin ir más lejos el del Auto de los Reyes Magos, de acuerdo con un uso que tal vez tuviera arraigo algo mayor en Toledo que en otras partes (cfr. avulo 'abuelo' en un documento de 1219 del Archivo Municipal de Toledo al que me refiero más adelante).

En realidad, lo característico de estas escribanías mozárabes es el empleo del árabe, porque sus documentos latinos y romances en poco se diferencian de los escritos en otros lugares, salvo, justamente, por las firmas en árabe y por los supuestos «mozarabismos» léxicos.

\footnotetext{
${ }^{94}$ Cfr. María Jesús Torrens, «La paleografía como instrumento de datación...», art. cit.
} 
Cuestión más compleja es la aducida por Hernández, con toda razón, de la falta de abreviaturas en la carta-puebla. A primera vista, ello apunta a un mayor foneticismo. Pero hay además razones escriptológicas, amén de culturales. La novedad (relativa a estas alturas) del uso del romance favorece la escritura completa de las palabras, mientras que la tradición irá introduciendo en este punto nuevas convenciones (por lo que aquí sólo afloran las que podían transplantarse directamente del latín, y es lo que sucede sobre todo en el segundo de nuestros documentos palentinos). Se ha de notar que la letra libraria de los siglos XII y XIII es poco proclive a la abreviación (se ve así en los códices regios de la segunda mitad del s. XIII), mientras que en los documentos, desde época alfonsí algunos tipos «pre-cursivos» anticipan el notable desarrollo que en la centuria siguiente tendrá la escritura por supresión, suspensión y compendio. Como hipótesis, puede sugerirse que este desarrollo tenga que ver con la sustitución de la lectura con emisión de voz por la lectura silente, lo que redundó en un menor foneticismo de la escritura, según muestra el empleo expletivo de $h$ (incluso en hes) y el desarrollo de los los llamados «grupos cultos» aun contra la etimología.

Wright señala que a la familia Apollechén se vincula el Auto de los Reyes Magos ${ }^{95}$, que mostraría una variante del romance escrito en este entorno mozárabe. Pero el mozarabismo no está presente en el Auto, y ya he señalado que determinados rasgos gráficos como $c h$ para $/ \mathrm{k} /$ tienen amplio empleo a fines del s. XIII.

Pero volvamos a nuestra serie documental en el momento en que la habíamos dejado. De 1193 es el interesante testamento de Sancha Núñez, de mano de Gutierre Fernández ${ }^{96}$. El documento está escrito en un latín convencional, aunque entreverado de palabras áulicas (23 «ceteres oves Marie alumpnae mee» ${ }^{97}$. Presenta las habituales inserciones romances en antropónimos, que si cabe destacar es porque éstos son nombres comunes fijados como apellidos de acuerdo con una costumbre que muestra más la documentación toledana que la de otros lugares: 3 «ut dentur [...] Petro mochacho», 26 «Petri mocho»

95 Roger Wright, «Latin and Romance in the Castilian Chancery, 1180-1230», Bulletin of Hispanic Studies, 73, 1996, págs. 115-128. Francisco Javier Hernández («Sobre los orígenes..., pág. 151, n. 75) nota el error de Wright de convertir a los hermanos Pedro y Domingo Alpolichén en uno. Domingo fue arcediano de la catedral de Toledo.

96 N. 203 = ACT Z.4.A.56.

97 La palabra alumno distaba de estar introducida en romance, por lo que es glosada en la General estoria: «Onde departimos nós ende d'esta guisa, que dize en el latín alumpnus por criado e alumpnus por sobrino, e otrossí alumpna por criada e alumpna por sobrina, e podemos allí dezir en aquella razón que Ovidio dize de Juno alumpna que se puede dezir tan bien por sobrina como por criada, ca fueron parientes Juno e aquellos dioses de la mar» (General estoria, Primera Parte, ed. Pedro Sánchez-Prieto Borja, Madrid, Fundación José Antonio de Castro, 2001, II, pág. 641 (Números, libro XXI, capítulo XI). 
(v. i. 5.5.1.). Por su grafía y por los valores fonéticos representados interesa la palabra mezquita: 5 «domus que fuit mezquita», junto a 17 «qui est super meskitam». La variación $-s k-\sim z q$ - refleja los dos polos de atracción entre los que se movían quienes escribieron estos documentos, y aquí muestra la disyuntiva entre la representación fonética más o menos fiel de la fricativa dental del árabe (que viene a coincidir con la representación habitual de la secuencia latina; Cfr. -sc- en conosco, padesco, etc.) y la fonética romance, que, como se ve, había llegado ya a la dentalización de $\mathrm{S}$ delante de velar sorda, por más que esto sea largamente enmascarado por el hábito de escribir $s c$, y que llega hasta muy tarde (tanto, que se solapará con el seseo). Pero el uso de $k$ en mezquita, dado que la grafía no aparece otras veces ante $-i$ en éste ni en otros documentos, puede ser muestra de la conciencia del carácter árabe de la palabra, de acuerdo con lo observado por Gribomont acerca de la presencia de esta grafía en códices bíblicos, entre otros los elaborados en Toledo, en los que el empleo de $k$ e $y$ se concentran en helenismos y voces de origen semítico ${ }^{98}$. Los toledanos baños del Caballillo se presentan como 616 «balneum de cavalil», donde no es seguro que $-i$ - represente reducción del diptongo, habida cuenta de la extensión gráfica de $i$ para [jé], aunque menor que la de $o \sim u$ para [wé] ${ }^{99}$.

Otro testamento, éste de $1194{ }^{100}$, muestra a las claras las contradicciones a las que había llegado el sistema escritura tradicional latino, por muy depurado que esté en apariencia, pues ha de ponerse continuamente al servicio de la expresión de usos romances. Domingo «Magridensis» da sus bienes a la iglesia catedral de Santa María. Entre otras propiedades un 4 «mensonem qui est in suburbio Toleti»; igual de llamativo es 8 «mando albergarie Sancte Marie una assehega et sabana et manta», o, también por la forma de referencias topológicas, 9 «vineas quas habeo in Pozola», 10 «in loco qui dicitur Olivar», observación esta última del todo convencional, y, a fines del. s. XII, ociosa ante las continuas intromisiones del romance, pero que viene a confirmar lo dicho sobre la conciencia de la distinción entre latín y romance en los topónimos ${ }^{101}$.

$\mathrm{Y}$ es que las posibilidades de la cultura del entorno de la catedral, que se manifiestan en la tenencia de libros tales como Las Bucólicas, legadas al sobrino del deán, que escribe la carta de testamento de «S» (¿Simeno?) ${ }^{102}$, canónigo de la «iglesia de Toledo», de poco sirven a la transmisión inequívoca de las mandas de un testamento, sobre todo cuando se refieren a objetos cotidianos:

\footnotetext{
98 «Conscience philologique chez les scribes du haut moyen âge», art. cit. en n. 9.

99 En una escritura en árabe del s. XII González Palencia lee «caballel»; en nota al dorso en romance, cabaliello (Ángel González Palencia, Los mozárabes de Toledo, op. cit., Volumen Preliminar, pág. 54, documento n. $^{\circ}$ 256).

${ }^{100} \mathrm{~N}^{\circ}{ }^{\circ} 204=$ ACT Z.4.A.14.

101 Véase también 12 «et mando sobrino meo», 18 «per manus mei alvacei».

102 N. ${ }^{\circ} 61=$ ACT X.12.B.2.1.
} 
14 «cetere (?) tenacule et alça trebes». La letra, del joven Juan, muy esmerada, es relativamente parecida a la de los diplomas regios.

Seguramente el mismo Juan, presbítero, escribió el testamento de Rodrigo, clérigo de San Nicolás ${ }^{103}$. La letra parece ser la misma. Revela la presión del romance en las opciones léxicas, como se ve en 16 «Maria creata mea», donde «criada» para 'sirviente' se opone a alumpna de ACT 203. Más interesante es comprobar que Juan tenía plenamente interiorizada la manera de escribir romance: 11 «pelle $m$ de coneios», con dominio de la representación castellana de la prepalatal sonora.

A finales del s. XII la escritura romance contaba con una cierta tradición en la catedral de Toledo, según muestra una carta de una «convenencia que faze Micael Ferrero per si et per suos aparceros» con Juan Pérez «de so las Mertiras» del año $1199^{104}$. La letra es más parecida a la que se emplea en los códices, incluso con distinción entre las dos formas alográficas de $r$, como se ve en

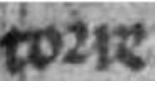

(torre), de acuerdo con una tendencia al parecer consolidada en Toledo antes que en otros lugares, y que será síntoma de la mejor caligrafía libraria. Con todo, la mejor letra no se aplicaba por entonces a los documentos en romance, como éste de carácter más humilde que los latinos, y estamos todavía lejos de la calidad que dio a la gótica libraria el contraste entre finos y gruesos (puede compararse con la del Fuero de Madrid). Sólo está en latín la subscripción («Bricius et connomine Lupus hanc kartam scripsit») y alguna palabra presentada en su forma tradicional latina (4 «el rex e el arzobispo»). El empleo de $k$ se limita al contexto ka (1 karta), a diferencia de la carta-puebla de Villa Algariva. Como era corriente en Toledo, y como se ve en tradiciones de escritura de otras zonas, no se refleja la diptongación de O breve tónica ( 5 foro 'fuero', 15 solo 'suelo'). La representación de la sibilantes se hace de acuerdo con un sistema bastante avanzado, por el que se distinguen las sibilantes alveolares (3 assi / 21 presentes) y las prepalatales sordas y sonoras (20 traxieren, 22 coxo / 3 iudicio, 6 trabaio, 21 paia), pero no las alveolares, ni entre las dorsodentales, por faltar ç como grafía distinta de $z$ (4 arzobispo, 15 alzastes) y emplearse $c$ donde se esperaría $z$ ( 3 iudicio). Como se ve, las opciones lingüísticas no difieren de las de Castilla la Vieja (1 ferrero, ni siquiera por su $f$-, también de largo empleo en escritorios situadas al norte del Guadarrama). Es en el léxico donde hallan acomodo usos característicos, aunque no exclusivos, de la onomástica toledana: 11 «a cide Iohannes».

103 N. ${ }^{\circ} 205$ = ACT Z.4.A.9.

${ }^{104}$ N. ${ }^{\circ} 177$, V.10.A.1.38. 
De la actitud favorable al uso del romance que se observa en el cabildo participaba, sin duda, el arzobispo Martín López de Pisuerga, que figura como comprador de unas casas en Talavera vendidas por el prior de Valle Peñose (?) en mayo de 1208 («Vall Pennose») ${ }^{105}$. Aunque no se dice quién escribió el documento, es probable que fuera alguien de la catedral. Los usos remiten a una de las tradiciones gráficas típicamente toledanas, que viene a coincidir con la empleada en el Auto de los Reyes Magos (lo que corrobora, con mayor certeza, el tipo de letra): ch para [k]: 2, 9 che 'que'. El carácter convencional de $o$ por ue (4 nostro, y quizá en 5 bonos en «morb. bonos e alfonsis») es puesto de relieve por 10 quemo, que apunta inequívocamente a una pronunciación [wé], mientras que $i e$, como hemos visto, estaba ya consolidada como grafía del diptongo procedente de $\mathrm{E}$ breve tónica ( 3 cidiello, 5 bien, a los que hay que sumar 7 orient). La documentación de 10 derechio muestra la extensión de un rasgo que suele identificarse como leonés, pero que hemos visto ya en el forzia de las Paces de Cabreros, e indica que, independientemente del origen geográfico de la solución fonética, su extensión a la escritura aconseja no utilizarlo apresuradamente para la adscripción dialectal no castellana del documento (por lo mismo que las Paces no son un documento «leonés»). Menos viable es la hipótesis mozarábica. Otros usos, con ser imposible adscribirlos a un lugar determinado, parecen frecuentes en Toledo, como 9 io ${ }^{106}$, así escrito en el Auto de los Reyes Magos ${ }^{107}$. La modalidad discursiva de matriz oral, tal como resalta por el cotejo con otros textos y por comparación con el uso hoy vigente, se muestra con nitidez en la organización sintáctica, con especificaciones circunstanciales, en este caso locativas, situadas «a la derecha»: 2 «en Talavera dentro en la villa en el barrio de Santa María» (hoy en el uso escrito se optaría más bien por una estructura «clasificadora»: «en el barrio de Santa María de Talavera»).

4.4. En 1209 obtiene la mitra arzobispal Rodrigo Jiménez de Rada, personaje de amplia cultura teológica y jurídica adquirida en París y Bolonia. Según suele repetirse, su actitud fue contraria al uso del romance. Donaciones de particulares no eclesiásticos, «género» que contaba con precedentes en romance, se escriben ahora en latín. Tal es el caso de ACT $04^{108}$, de 1211, por desgracia muy deteriorado. Está escrito en una preciosa letra estilizada, pero no

\footnotetext{
${ }^{105}$ N.$^{\circ} 161$ = ACT Z.3.C.1.7. Están en latín la invocación («In Dei nomine»), la data y las confirmaciones, incluida la genérica del convento ( $12 \ll$ Et totum capitulum confirmat. Huius rei testes sunt»).

${ }^{106}$ Mientras que en el incipit era obligado ego (1 «ego don Iohannes»).

107 A lo largo del s. XIII io es la forma habitual en los pergaminos del monasterios de Santa María de Aguilar de Campoo (Palencia) y de Oña (Burgos).

108 A.3.6.1.3.
} 
tanto como ACT 178 por el que Diego López y su mujer Toda Pérez dan a la catedral de Toledo la villa de «Alcubelet». Para su caracterización sintáctica y léxica, v. «apud Toletum». El citado ACT $178^{109}$, de agosto de 1213, emplea la que será la letra de privilegios romances bajo Fernando III, caracterizada por el módulo pequeño, la gran prolongación de las astas y la consiguiente separación de renglones, además de por el mínimo recurso a las abreviaturas, rasgo éste que se ha destacado para el romance. La calidad del latín (mayor en los segmentos más formales como el protocolo inicial, que alcanza cierta solemnidad) no es incompatible con la glosa de dictado románico, de acuerdo con el procedimiento de la lectio, hábito intelectual bien aprendido en la escuela, pero tal favorecido por la presentación en voz alta del contenido: «et ista molendina sunt in una domo scilicet in prima casa». Naturalmente, no podían faltar formas romances (en particular de origen árabe) en referencias materiales y locativas: arabismos léxicos los topónimos en forma romance: 3 «in azudam que dicitur abarisco», 13 «in azuda de Corral Rubio».

El día de San Martín de 1213, don Jordán, chantre de la catedral (capis$(o l)$, da algunas propiedades, entre ellas una bodega, a don Gonzalo «el carnicero» ${ }^{110}$. El romance se introduce desde el primer verbo («Notum sit omnibus quod ego... arrendo»), y se emplea de manera consistente salvo en la data tópica al final y la inserción parcial de ésta al inicio ( 3 «in die sancti Martini»). Es de los primeros documentos toledanos que muestran ue (8 fueras, 14 cuenta, pero boves, 7 molas). Por descontado, se refleja ie $(7$ semient, mientas que 2 arrendo ha de contarse al lado de los verbos que en su étimo tienen $\mathrm{E}$ larga y diptongaron analógicamente ${ }^{111}$ ). La grafía -ni- en 8 laniadas ha de entenderse más bien como un modo de representar la palatal nasal, pero también puede ser eco de la variación entre [n] y [nj] todavía hoy frecuente en Castilla-la Mancha y en otras regiones (p. ej., Antoño $\sim$ Antonio) ${ }^{112}$. No muestra el documento la distinción entre las sibilantes dorsodentales sorda y sonora: 11 Gonzalvo, 14 conpeçamiento.

Pero la tradición de escritura romance no se había afianzado en Toledo tempranamente sólo en la catedral. En el mes de mayo del año de Cristo de 1219 («sub era $\mathrm{M}^{\mathrm{a}}$. $\mathrm{CC}^{\mathrm{a}} \mathrm{L}^{\mathrm{a}}$ VII ${ }^{\mathrm{a}}$ ) Pedro Yuáñez (o Iváñez) preparó la nota de tres cartas de compraventa en favor de Don Rodrigo Ximénez de Rada. Pedro Yuáñez era subdiácono de San Vicente, que no es una de las parroquias mozárabes. El contenido de estas cartas resulta un poco enigmático por el uso de la preposición $d e$. Como no conocemos al cien por cien la gramática de la len-

\footnotetext{
109 V.10.A.1.3a.

110 ACT $62=$ X.3.D.6.7.

111 Todavía en el s. XV, «yo sembro».

112 Cfr. Francisco Moreno, «Despalatalización de $\tilde{n}$ en español», Lingüística Española Actual, X 1988, págs. 61-72.
} 
gua castellana medieval dejamos un margen de duda. Los tres documentos dicen: «vende don (fulano) del arzobispo don $\mathrm{R}^{\circ}$ Simenez». La prep. de vale aquí como 'a', de tal modo que en AMT 6 «vende don Johan Fagund el ferrero del arzobispo don $\mathrm{R}^{\mathrm{o}}$ simenez que Dios salve la ratión que ha en Iumela» no ha de entenderse que don Juan Fagund era herrero del arzobispo, sino 'vende al arzobispo'. La letra de estos documentos es distinta de la que se solía emplear en la catedral, menos perfilada, con menos contrastes y menos quebradas, más redondeada que angulosa, con astas prolongadas que se curvan, pero sin la estilización de los mejores diplomas. Creo que las tres cartas del AMT de 1219 son de la misma mano; no es imposible que de la de Pedro Yuáñez (el texto dice que hizo la nota). Los documentos están en un romance bien reflejado, salvo la invocación del protocolo y la data. Presenta firmas en árabe; pero a mi entender esto no significa necesariamente que proceda de una escribanía mozárabe, pero sí, al menos, que hay mozárabes como testigos. Lo que sí es claro es que su formulación sigue modelos árabes ${ }^{113}$.

Los usos gráficos de estos tres ejemplares coinciden solo en parte con los de los diplomas de Fernando III en cuestiones como la representación de los diptongos: 60,9 «a quis quiere», pero 60,9 sobrelibo 'sobrelievo', 59,6 asintalo 'asiéntalo'; 6,4 pues, 6,8 fuero; el mismo documento 60 trae, como los otros, 5 pues, 8 fuero, pero 1 auulo 'avuelo'; véase también 6,6 bono («moravedi alfonsi bono»), pero el adjetivo bono pervive así en época de Alfonso X, cuando ya no había más casos de $o$ por [wé] salvo éste y, más ocasionalmente, novo 'nuevo'; en realidad entró en una variación de la que es muestra el par como cuemo, o, con implicaciones semánticas, son $\sim$ sueno ${ }^{114}$. Entre las sibilantes dentales tenemos las de 59,6 recibe, 6,3 cerca, para la sorda, pero no se marca la sonora. La distinción entre ese sorda y sonora se refleja bien: 6 passa, 6,5 passada, 6,6 peso, sustantivo. La sorda la escriben con $x$ en 59,4 exidas, pero todos 1 Simenez; tampoco fue raro marcar este sonido con ss, como en 6,4 yssios («yssios d'ello el vendedor»), de exir. La sonora, en 59,1 60,1 jumela; en 6,1 iumela. Por supuesto, en estos documentos las soluciones fonéticas son castellanas (salvo que 59,1 filia se quiera interpretar fonéticamente como algo distinto de la prepalatal sonora; tampoco se observa pervivencia de diptongos decrecientes $(6,1$ ferrero $)$. El uso de $b$ - $v$ coincide con el que se generalizó en la tradición cancilleresca fernandina y alfonsí. Cabe destacar también el empleo de $m$ ante $b$ : 6,4 conombrado. Otro aspecto interesante es el de la representación de lo que seguramente era una mediopalatal (aunque no todos admiten la

\footnotetext{
${ }^{113}$ Compárese con la n. ${ }^{\circ} 475$ de Los cartularios de Toledo..., op. cit.

114 A pesar del título, trata todos los casos mencionados de variación $o \sim$ ue Jesús Moreno Bernal, «Sobre el significado de son y sueno en español medieval», en Homenaje a A. Zamora Vicente, vol. I, Historia de la lengua. El español contemporáneo, Madrid, Castalia, 1988, págs. 179-189.
} 
consonantización temprana, por lo menos en posición inicial): 6,8 oyo 'oyó'; parece mostrar una situación más atrasada 6,3 «hermo», pero Torrens demostró en su estudio del Fuero de Alcalá que se rechaza ie en posición inicial y se recurre a $h$ como soporte del signo de abreviación (véase lo que se dirá enseguida acerca de $u e-)^{115}$. El uso de un modelo (o una preferencia personal) explica la coincidencia en $l$ por $l l$ : 4 «e no se entorpó en elo».

ACT 06 (A.11.6.1.2.), de 1221, es una carta en romance por la que Miguel Estévanez, archidiácono de Calatrava, da sus posesiones de los molinos de Alfita al arzobispo. El uso del romance en este caso no indica aceptación por parte de Don Rodrigo, al menos no en 1221, sino que para esta fecha en los documentos toledanos de compraventa y donación se había consolidado su uso. La mandó escribir Domingo, «preceptor» de la catedral: 22 «Ego d. precentor toletanus testis et iusi scribere pro me». La letra es toledana típica. Hay representación de los diptongos (6 arevaliello, 4 fuera, 8 despues, 16 mueble, pero 7 «orta de la thesorería» y 6 avolo). A estas alturas creo que hay una explicación clara: el rechazo de ue- en inicial de palabra ( Cfr. órfano en el Fuero de Alcalá; es posible que este rasgo apunte a una cronología especialmente temprana del Fuero, puede que no muy posterior a 1230). El desarrollo de $h$ - ante ue quiere evitar esta secuencia inicial, y acierta de lleno Valdés al señalar que $\sin$ h- estas palabras «casi no se pueden pronunciar» (se refería, claro está, a la ambigüedad entre [be] y [wé]) ${ }^{116}$. Una razón también paleográfica, evitar la secuencia gráfica uи explica que se dé 6 auolo y no auuelo. En la escritura de las sibilantes también manifiesta el documento un rasgo de una tradición que está a punto de llegar a su fin en Toledo: no distingue dorsodental sorda de sonora por no tener ç (así 3 azuda, 2 arzobispo). No quiere decir esto que por entonces no se conociera la distinción en el cabildo. En este sentido cabe interpretar que Domingo Zapata, «parcionero» de la catedral, ponga de su puño y letra su apellido como çapata entre las firmas de la carta. La oposición entre alveolares la muestra 15 successores frente a 9 casa. Caso de escritura tradicional es 13 filio, frente a 18 meiorare. En lo que concierne al léxico, importa la presencia de la palabra árabe 17 mariahadarac, que indica la difusión en ambiente no mozárabe de términos jurídicos usados por las escribanías mozárabes. Pero quizá lo más llamativo de este documento sea su preciosa caligrafía de astas curvas contrastadas, según un uso librario ejecutado con cierta torpeza, en cambio, en los documentos de 1219 del Archivo Municipal de Toledo.

También pertenece al mismo uso típicamente toledano, según creo, una

115 María Jesús Torrens, Edición y estudio lingüístico del Fuero de Alcalá (Fuero Viejo), Alcalá de Henares, Fundación Colegio del Rey, 2002.

116 Cfr. Cómo editar los textos medievales..., op. cit., págs. 118-119. 
carta romance dada en Guadalajara en $1221^{117}$. Por ella, el concejo de Guadalajara da Trijueque al arzobispo de Toledo, pero todo indica que fue un clérigo de la catedral quien la escribió. La distinción paleográfica entre $c ̧$ y $z$ ni siquiera está apuntada:

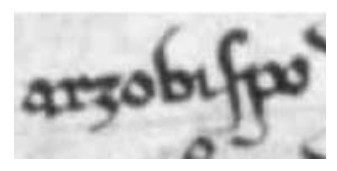

Para valorar la actitud de Rodrigo Jiménez de Rada hacia el romance nos sirven los fueros que en 1223 otorgó a las aldeas de Alcalá $\left(\mathrm{N}^{\circ} 8=\mathrm{ACT}\right.$ A.3.A.1.12a), a Talamanca ( $\mathrm{N}^{\circ} 207=$ ACT Z.3.b.1.4.), a Brihuega $\left(\mathrm{N}^{\circ} 9=\mathrm{ACT}\right.$ A.3.A.3.3a) y a San Justo de Alcalá ( $\mathrm{N}^{\circ} 7=$ ACT A.3.A.1.14), todos ellos en latín, de acuerdo con un uso favorecido, sin duda, por la existencia de un modelo previo, pero sin olvidar que para la versión «arromanzada» existía ya un modelo en latín bárbaro mezclado con romance al menos desde el Fuero de Belinchón.

En 1226 seguramente no había cambiado la actitud del arzobispo, sino que fueron razones prácticas las que hacen que el 26 de noviembre promueva una «avenencia» que se expresa en romance entre los herederos de los derechos sobre las aceñas de «Medianedo Morziello», en el término de Alfamín, y don Gonzalo, «familiar del papa y sacristán de Osma», que las tenían a la sazón en préstamo de la catedral ${ }^{118}$. El documento se valida con los sellos real y arzobispal. Don Rodrigo, además, firma de su puño y letra, en caligrafía que a todas luces manifiesta su formación europea, y que contrasta con la letra típicamente toledana del documento. Pero lo llamativo es la ortografía avanzada, pues ç se opone a z: 3 Gonçalvo, 4 arçobispo, 11 sarços, y también 7 raçion, que indica que $c$ es aquí ya una variante alográfica de $c$ y no $z$. La sonora se marca con z: 3 fiziemos. La presencia de hy para la conjunción copulativa apunta a una tradición al parecer más arraigada en Toledo que en otras partes.

4.5. Del 22 de septiembre de 1234 es un documento romance de la cancillería, dado en San Esteban de Gormaz ${ }^{119}$ que manifiesta usos ortográficos que serán los vigentes bajo Fernando III y Alfonso X (3 fuessen / 5 osado; 2 dixieron / 3 Taio; no hay ejemplos de ç, y sí de $z$ en fazién). Pero del mismo año es ACT $134^{120}$, que juzgo fundamental para el conocimiento de los orígenes de la ortografía «oficial», pues muestra que la catedral de Toledo quedó

\footnotetext{
117 N. ${ }^{\circ} 133=$ ACT 0.2.Q.9.2.

118 N. ${ }^{\circ} 10=$ A.2.B.1.1. Publicado íntegro en Francisco Javier Hernández, Los cartularios de la catedral de Toledo..., op. cit., n. ${ }^{\circ} 419$.

119 N. ${ }^{\circ} 136$ = ACT O.2.B.1.1.

120 ACT 0.2.F.1.1.
} 
desvinculada de la cancillería regia durante unos años cruciales. La cancillería recae ahora en Don Juan, el obispo de Osma, mientras que Rodrigo Jiménez de Rada tenía su propio canciller, a la sazón don Pedro (ya hubo precedentes, aunque no parece que fuera una práctica continuada). A distancia, uno casi ve un acto de desagravio por parte del arzobispo. Este diploma muestra el control efectivo del arzobispo de Osma sobre la cancillería regia. Se trata de un cambio de las posesiones de Oter de Siellas que el metropolitano de Toledo tenía por las de «Fogeda», a la sazón en manos del obispo de Osma. Tordesillas se vincula así a la cancillería (o mejor dicho, al canciller regio). Pero hablaba de control efectivo. Creo que éste aunque no es un documento propiamente cancilleresco (en este caso la iussio no es del rey) sí se confeccionó en la cancillería. Hernández ${ }^{121}$ sugiere que las firmas de los testigos toledanos (testigos in absentia) se escribieran en Talamanca, según reza la data tópica, mientras que el obispo de Osma se encargaría de la redacción del documento y de la escrituración de los nombres de sus testigos. Por mi parte, había notado este cambio de mano, y me parece la de Hernández explicación pausible, con la salvedad de que es probable que hombres de la cancillería regia por mandado del obispo de Osma se personaran en Talamanca para la concordia con el arzobispo. A favor de la autoría «toledana» de la parte final del documento habla la doble datación por la era de España y por la cristiana, que no se da en los diplomas de la cancillería de Fernando III, pero que sí muestran algunos diplomas de la catedral de Toledo, como uno de $1248^{122}$. La elaboración material del documento, su letra, sus usos gráficos y sus valores linguísticos prueban cuán importante fue el paso al obispo de Osma de la cancillería real. La ortografía es desde este temprano documento regio en romance del todo homologable a la alfonsí, incluso en la distinción ç/z (1 arçobispo, 7 collaços / 10 fazer; incluso se emplea $c$ para marcar la dental implosiva en 5 «villa $\mathrm{Na}$ çriel»). Lo mismo puede decirse de /s/ / /z/ (10 essa, 3 assi / 2 casas $)$ o de /s/ $/ / \mathrm{z} /$ (3 8 exidas). Aunque carezca de transcendencia fonética, es general $m$ ante b: 7 cambio, 7 connombrados, 11 nombres ${ }^{123}$.

En los años 30 del s. XIII otros escritorios habían incorporado algunos hallazgos ortográficos que permitían una adecuada representación de la fonética. Creo que alguien vinculado a la catedral de Palencia escribió un documento datado en Villaumbrales en 1233 por el que Rodrigo Álvarez y su mujer venden la villa de San Cristóbal ${ }^{124}$. La distinción entre dorsodentales sorda y sonora se marca en 1 coraçón frente a 2 dizen.

\footnotetext{
${ }^{121}$ Los cartularios de Toledo, op. cit., $\mathrm{n}^{\mathrm{o}} \mathrm{xxx}$.

122 N. ${ }^{\circ} 142$ = ACT X.11.G.1.1.

${ }^{123}$ La brevedad de los documentos no permite concluir un cumplimiento obligatorio de esta ley. Ni siquiera los testimonios alfonsíes son uniformes en esto.

${ }^{124}$ N. ${ }^{\circ} 131=$ ACT I.3.11.1.2a. 
La progresión ortográfica no era lineal. Todavía en 1231 a iniciativa de Don Rodrigo Jiménez de Rada se dan a Domingo Yáñez, su criado (alumpno), algunas posesiones que la catedral tiene en Guadalajara ${ }^{125}$. El documento se redacta en latín, lo que prueba que ni siquiera por entonces la actitud era favorable al romance. El mismo año, el «precentor» de la catedral manda escribir una carta de donación (ACT 76). Esta muestra la típica letra toledana, que todavía no había incorporado todas las novedades ortográficas: 1 facemos, 6 facer, aunque ya tenía ç en 1 conosçuda. Sí presenta, en cambio, el resto de convenciones, como $m$ ante $b$ y $p$ ( 2 connombrados, 7 nombres).

La escritura romance del cabildo sigue patrones tradicionales todavía a mediados de los años treinta, y la que hemos llamado letra típica «toledana» adopta una morfología muy definida, aunque cambiante según la ejecución. Cuando ésta es cuidadosa, el parecido con el uso librario resulta evidente, según se ve en ACT 105, de $1235^{126}$. Aunque la brevedad de muchos documentos impide conclusiones seguras sobre los usos gráficos, y también, su falta de uniformidad, lo cierto es que ésta contrasta claramente con la mayor estabilidad de la escritura cancilleresca por los mismos años, amén de que el tipo de letra cancilleresca es netamente distinto. La falta de uniformidad de los diplomas toledanos puede ser manifestación de que en el cabildo (y en el entorno del catedral) todos dominaban la práctica de la escritura, mientras que en otros centros, como los monasterios, durante años una sola persona escribe todos o casi todos los documentos. Munio, hijo de Juan Miguel el Colmenero, es autor de una carta con usos como 1 mulier, filio, aunque también se lee fijo. Menos ha de sorprender 8 octjdente (la palabra se escribe alguna vez así en el códice BNM 816 de la General estoria, pero occidente en el Auto de los Reyes Magos). Tal vez carrea en 17 «la carrea que va a fuente teiada» refleje una variante sociolingüística de nivel popular, si no es mero lapsus.

Un motivo importante para la variación ortográfica es la dispar procedencia de quienes ocuparon un cargo en la catedral o, en general, de quienes escribían sus diplomas. De procedencia tal vez asturiana (o, al menos, habría aprendido a escribir en Asturias) era el autor de ACT 78, de $1237^{127}$, que emplea $g$ por ge (5 page 'pague'), «tro a» («que faga toda la paret ques tiene con las otras casas nuestras de nueuo tro a sommo»), cabrido (5 «segund el fuero de cabrido», pero 1 «el cabildo de Santa María») o pola (6 «Conpieça pola festa de sant Sebastián»), usos que bien podrían encajar con los del monasterio asturiano de Belmonte.

\footnotetext{
${ }^{125} \mathrm{~N}^{\circ} 60$ = ACT O.2.9.4

${ }^{126}$ Destaca la forma de la $s$ de doble panza, en realidad con trazo inferior prolongado en una curva amplia.

${ }^{127}$ E.11.A.15.
} 
Del mismo año es ACT $180^{128}$, que interesa por estar en línea con la escritura cancilleresca, pero no exactamente en la modalidad de privilegios, sino con los usos de cartas plomadas y de otras clases de documentos, como los mandatos, que adquirirán gran importancia bajo Alfonso X. Ahora ese tipo de letra se encuentra en su fase inicial (puede apreciarse la ç con cedilla prolongada de trazo similar a la de cartas plomadas de Fernando III). Se reparte bien $c ̧$ y z: 37 arçobispo, 14 siguença, 15 faças frente a 13 «Pedro Felizes», 18 vezinos. Es éste de los primeros documentos toledanos en mostrar una ortografía homologable a la de la cancillería de Fernando III (no se aparta de ésta la opción 8 yuro, frente a juro, de acuerdo con una variación que todavía mostraron los códices alfonsíes, y creo que en menor medida los diplomas). En esa línea está 5 huerto, con una $h$ - que, como hemos visto, permite superar la escritura orta, todavía vigente en diplomas como el antes citado, que sí adopta, en cambio, -ue- en posición interior. Esos hallazgos ortográficos están igualmente incorporados en ACT $179^{129}$, también de 1237, escrito en letra irregular por García (Garssias), canónigo de la catedral. «Diego Sadornín, alcalde de Talavera», compró una heredad a «doña Muñoza» en la aldea de «Luziellos» (hoy Navaluzillos), para «don Martín Yuáñez, notario del rey», que le dio el dinero. Se ha de notar la típica cedilla en 1 conoçuda, y mejor en 5 Muñoça, que se distingue con claridad de $z$ empleada en 3 Luziellos, 8 dize. Muestra su adscripción toledana 3 vertad, presente 11 veces en el Auto de los Reyes Magos por 3 de verdad aunque ni con mucho puede considerarse exclusivo de esta tradición de escritura ${ }^{130}$.

De agosto de ese mismo año de 1237 es el testamento de Gonzalo Hernández, canónigo de Toledo, que deja sus bienes a la catedral ${ }^{131}$ (ACT 192). Presenta la peculiaridad, tal vez no solo ortográfica, de 4 jermano. Para la modalidad lingüística seguida quizá interese la terminación -illa en Fatomilla (1314 «la mi mora que dizen Fatomilla»), donde el diminutivo de Fátima («Mando que si Fátima quisiere ser cristiana») se introduce con «que dizen», lo que tal vez indique una cierta conciencia del nivel sociolingüístico, que favorece una representación más perspicua del uso oral (recuérdese el empleo de «qui vocatur» en los documentos latinos).

En 1239, el romance era digno de ir presentado por una buena letra aunque

\footnotetext{
128 V.1.A.1.1.

129 V.6.K.1.1.

130 Según señaló Rafael Lapesa, vertaderos aparece en el Fuero de Madrid y en un documentos de Burgos de 1222, aparte de en la Fazienda de Ultramar («Mozárabe y catalán o gascón en el Auto de los Reyes Magos», en Miscellània Aramon i Serra, Barcelona, Curial, 1983, págs. 277-294: 140). También está en documentos navarros, p. ej., en Documentos españoles anteriores a 1700, n. 936 (1357), Pamplona 31 y 982 (1358) [San Pedro de Ribes] 38 vertat.

${ }^{131}$ N. ${ }^{\circ} 192=$ ACT Z.4.B.41.
} 
el asunto tratado no fuera de especial relevancia ni el documento en sí tuviera solemnidad alguna. Es el caso de ACT $64^{132}$, de 1239, de caligrafía parecida a la de las cartas plomadas de Fernando III. El uso de $m$ ante $b$ o $p$ es general: 7 comprar, 9 conombrado, 14 hombre. Se emplea ç en 2 Gonçalvo... pero 1 conozuda, 13 arenzada...

Los ejemplos podrían multiplicarse. El sistema llamado alfonsí era conocido en la catedral a finales de los 30 (p. ej. ACT 12, de $1239^{133}$ ), pero aparte de otros detalles menores, la oposición entre dorsontales sordas y sonoras no se solía manifestar. Es lo que sucede todavía en una carta de 1248 por la que el deán D. Miguel y el cabildo arriendan unas casas ${ }^{134}$. No se adopta ç: 2 Lázaro, 9 comenzarán.

Don Rodrigo Jiménez debió de otorgar el fuero romance de Alcalá hacia 1233 como pronto. De naturaleza muy distinta es la carta-puebla de Alpuébrega (al este de Polán), de $1242^{135}$, en romance, lo que indica ya claramente una aceptación del empleo del ya no tan nuevo código código de escritura por parte del arzobispo. Esta carta-puebla resulta interesante por adoptar un tipo de letra estilizada, de módulo pequeño, con marcada prolongación de astas que la aproximaría a la de los privilegios de Fernando III si no fuera por su ejecución rápida, que imprime una leve cursividad en el retorno de las astas horizontales, en particular de $g$. Del mismo año es ACT $13^{136}$, en el que se escribe 1 connoçuda, 15 Gonçalvo y 15 arçobispo (frente a 8 fazer), pero 4 pozo, que contrasta con el uso cancilleresco. Cierta extensión tuvo el empleo de $c$ ante $a, o, u$ para la dorsodental africada sorda: 15 Taracona. Creo que la palabra está corregida; alguien, no sé cuándo, ha añadido la cedilla (el mismo uso muestra el Libro de los animales que caçan, obra más conocido como «Moamín», contenido en el MS Res. 270 de la BNE, de hacia 1250).

Una leve cursividad manifiesta también un otorgamiento de merced del arzobispo don Rodrigo ${ }^{137}$, de 31 de marzo de 1246, particularmente en la prolongación de las linetas de abreviación. La distinción ç/z se muestra de manera consistente.

Mediado el siglo parece que el empleo de $c ̧$ se extendió a contexto $e, i$, según muestra en 1248 ACT $140^{138}$ ( 2 alcaçer, 4 terçia), lo que será corriente en los libros alfonsíes, y mucho menos en los diplomas regios. El documento lo escribió Diego Yuáñez, quien subscribe algún otro texto catedralicio. Usos

\footnotetext{
132 X.3.D.6.9.

133 A.3.B.1.4.

134 N. ${ }^{\circ} 195=$ ACT Z.11.B.3.12.

135 N. ${ }^{\circ} 11=$ ACT A.4.S.1.1.

136 A.5.A.1.9.

137 N. 67 = ACT X.9.E.I.6.

138 O.1.E.1.10.
} 
que, sin ser exclusivos, disuenan de los cancillerescos son heguas 'yeguas' y Olaha 'Olalla'.

La presencia en la catedral de canónigos de diversa procedencia parece manifiestarse en un documento por el que el deán don Miguel y el cabildo de Santa María dan en alquiler (loguer) unas casas a «don Ferrand Yáñez el tegero» ${ }^{139}$, de 1245 . No se corresponde con el uso castellano habitual 2 caleyuela, mientras que 2 bario, con $r$ para $/ \mathrm{r} /$, aunque desechado de manera casi absoluta de la tradición cancilleresca, muestra su presencia en bastantes tradiciones de escritura a lo largo de toda la Edad Media. Quien escribió esta carta distinguía bien entre ç y $z$ ( 2 plaça, 4 plaço / 7 fazer), lo que indica que el desarrollo de una ortografía avanzada no fue exclusivo de un determinado escritorio.

4.6. A mediados del s. XIII el empleo de romance en los documentos elaborados por miembros del cabildo era general, pero todavía Don Juan de Medina de Pomar, cuyo arzobispado apenas alcanzó los cinco meses, emite el mismo día de su muerte, el 20 de julio de 1248, en Tamajón, un documento latino por el que dona algunas posesiones al cabildo de la catedral ${ }^{140}$. La letra es parecida a la que se empleará en los mandatos regios, con ciertos rasgos cursivos.

No fue mucho más duradero el arzobispado del sucesor de Don Juan, Gutierre Ruiz Dolea (1249-1250), conocido por la consagración de la mezquita de Córdoba para el culto cristiano. Su sucesor en el arzobispado fue Sancho de Castilla, hijo de Fernando III, electo de la sede primada cuando no contaba la edad canónica, por lo que no usará el título de arzobispo hasta 1259. Un documento de 29 de abril de 1249 lo intitula «arcediano de Toledo» ${ }^{141}$. En él reconoce que no tiene derechos sobre 3-4 «las casa e la varca que avié en Sant Just». El documento lleva la firma de «D. Çapata», ahora relacionado como arcediano de Madrid. «Magister L.» (¿Lorenzo?), arcediano de Talavera fue testigo («et scribere [fecit] per me»). La letra es igual que la de los mandatos de Alfonso X. Que la obra de Alfonso X esté vinculada a Toledo es algo que se ha dado por supuesto en numerosas ocasiones, pero otra cosa distinta es que ello se haya apoyado en hechos lingüísticos concretos. La catedral de Toledo proporcionó a Alfonso X el ambiante intelectual apropiado para llevar a cabo su magna labor científica e historiográfica. La presencia en Toledo de sabios judíos conocedores del árabe constituía un elemento indispensable para la ambiciosa obra patrocinada por el Rey Sabio. Y toledanos serían no pocos cola-

\footnotetext{
${ }^{139}$ N. ${ }^{\circ} 83=$ ACT E.9.C.2.1.3.

140 N. ${ }^{\circ} 142=$ ACT X.11.G.1.1.

${ }^{141}$ N. ${ }^{\circ} 183=$ ACT V.2.D.1.3.
} 
boradores cristianos del rey sabio, como Martín Pérez «de Maqueda», villa distante pocos kilómetros de la capital del Tajo. Y la vinculación más evidente es la del arzobispo Sancho, hijo de Fernando III. Pero a estas alturas, la cancillería castellana ya tenía una larga experiencia en el uso del romance y había constituido un sistema escriptológico muy apropiado para la representación de la fonética castellana. Personas como el arcidiano «maestre Ferrán», que trabajaron como notarios del rey a las órdenes de su hermano Sancho ${ }^{142}$, no tuvieron que hacer sino continuar los usos establecidos en tiempo del unificador de Castilla y León. Prueba de ello, ya en era del rey Sabio, es la carta por la que el cabildo de Santa María arrienda una viña a Martín Domingo en $1254^{143}$. La letra es igual que la de las cartas plomadas empleada por los escribanos de Fernando III en los últimos años de su reinado, y que se había hecho habitual en la catedral. También la ortografía es del todo homologable ( 5 saçones, 6 plaças / 6 faziendo). Puede compararse con ACT 85 (E.11.F.11), de 1250, o con ACT 69 (Z.6.G.1.7a), de 1250, escrita por Pedro «de Cibdat» ${ }^{144}$. El mismo Sancho emplea una elegante letra de incipiente cursividad que en su época se usó en diplomas de la cancillería, pero nunca, que sepamos en los códices de la Cámara Regia (cfr. el engarce entre $s$ y $t$ en Castelle):

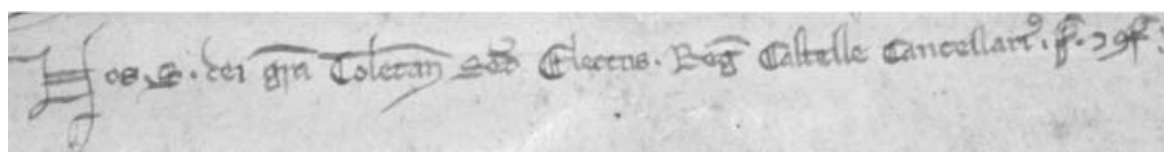

[ACT $112(1254)]$

\section{CONCLUSIONES PROVISIONALES}

El recorrido cronológico por la documentación toledana nos ha permitido acercarnos al desarrollo de la escritura romance. Una presentación como ésta tiene quizá el inconveniente de exigir al lector más esfuerzo para aprehender las líneas generales de ese desarrollo, pero es el único procedimiento que permite sustraerse a una concepción de la historia de la escritura como un proceso simple y monocorde, lo que no se correspondería ni de lejos con la realidad de los hechos. Antes al contrario, si algo caracteriza el desarrollo de la puesta por escrito del romance es la diversidad de tendencias y de opciones simultáneas que se presentan no sólo comparando diferentes escritorios entre sí, sino dentro

142 ACT ¿?? de 1254 (A.3.A.3.14.) 11 «Aparicio $\mathrm{P}<$ er $>$ ez la fizo por $m a<n>$ dado del arcediano Maestre Ferrand notario del Rey».

$143 \mathrm{Sin} \mathrm{n}^{\circ}$ (ACT O.1.6.1.3.).

144 Es igual que la del 13 de abril de 1251 otorgada al concejo de Guadalajara (Pedro Sánchez-Prieto Borja, coord., Textos para la historia del español. II Archivo Municipal de Guadalajara, Alcalá de Henares, Universidad de Alcalá, 1995). 
de un mismo ámbito de escritura. Y esto es así especialmente en el caso de la ciudad de Toledo, donde, amén de coexistir diferentes entidades en las que la práctica de la escritura es habitual (notarías mozárabes, parroquias, catedral, cancillería regia en algunos períodos), ni siquiera en el entorno de la catedral puede hablarse de usos uniformes.

Esta falta de uniformidad en el grado de adopción de la escritura romance halla confirmación en la diversidad que se observa en los diferentes niveles lingüísticos (grafía y fonética, morfología), lo cual tiene importantes consecuencias metodológicas. El examen de algunos de los rasgos lingüísticos pondrá esta disparidad de manifiesto, y además, contribuirá a un conocimiento de primera mano de los rasgos de lengua de la documentación toledana y, con toda la parcialidad que deriva de la especial relación entre escritura y lengua hablada, al conocimiento del romance en Toledo. Según vengo defendiendo desde hace algunos años, un examen de los rasgos de lengua de un texto medieval, en particular del nivel fonético, no puede empezar sin más por la valoración fonética, pues ésta ha de hacerse, según se dijo, en el marco de la historia de la escritura, por los fuertes condicionamientos que la paleografía, en particular el tipo de letra empleado, impone a las opciones gráficas, de las que, obviamente, habrá que deducir los valores fonéticos (recuérdes la motivación escriptológica para $o$ en vez de $u e$ en posición inicial absoluta de palabra).

Un examen atento a la historia de la escritura demuestra la coexistencia de diferentes tradiciones en Castilla y León en el período aquí examinado, y, claro está, en cualquier otro. Con todo, la época examinada es crucial, por ser en ésta cuando se configuran de manera diferenciada las dos principales tradiciones escriturarias del s. XIII, la documental de la cancillería de Fernando III y Alfonso X, y la libraria de la Cámara Regia alfonsí. Ambos tipos están representados en Toledo, pero creo que en diferente manera y con diferente relación cronológica con los usos «oficiales». En los documentos latinos emanados del arzobispo Jiménez de Rada se emplea una elegante letra caligráfica que, lejos de la habitual denominación como «carolina», hay que considerar plenamente gótica, y que aunque se empleó inicialmente en libros litúrgicos se adopta en el ámbito documental. Este tipo de letra estaba difundida en los mejores centros de la latinidad, y resulta poco factible en el estado actual de las investigaciones atribuir la prioridad a unos lugares o a otros. En la corona de Castilla, las catedrales de Palencia, Osma o Toledo serán centros destacados de ese cultivo del latín que tiene como efecto inmediato la adopción de un tipo de letra que se extiende al hilo de la difusión de los códices. La vinculación directa de este tipo de letra con la de la cancillería regia bajo Fernando III parece clara, y bien pudo ser el modelo para el tipo empleado en privilegios reales y cartas plomadas, contando con que la de éstas es más variable que la de privilegios. No cabe, creo yo, establecer una vinculación directa entre escritura en Toledo y le- 
tra de la cancillería de Fernando III, pues documentos romances como el examinado de mano de Álvar García de Frómista, de 1234, mostraban un tipo de escritura tan perfeccionado como el que más de la tradición latina, con su característico curvados contrapuestos en la letras como $s$ alta o $f$, mientras que este empleo no se encuentra en los documentos romances de Toledo hasta fecha más tardía, y aun así sin llegar a la perfección formal de los diplomas regios. La vinculación a Toledo de la cancillería no fue siempre efectiva, y en la época del obispo D. Juan, fue Osma quien ostentó el privilegio.

Otra línea escrituraria distinta es la representada por la biblioteca y escritorio capitular. A esta conexión apuntó Hernández ${ }^{145}$. Una vez más, el plano paleográfico nos da una clave interpretativa precisa. Los cartularios de la catedral de Toledo (especialmente el 996B de la primera mitad del s. XIII ${ }^{146}$ ), presentan un tipo de letra muy similar a la que emplearán los códices regios alfonsíes. Algún cartulario posterior presenta una letra no ya parecida, sino idéntica. Y cabe destacar la figura de Pérez de Maqueda, «escribano de los libros de muy noble rey don Alfonso», según reza el éxplicit de Urb. Lat. 539 de la Biblioteca Vaticana y notario regio que firma algunos diplomas. La disociación entre cancillería y escritorio regio ¿es de carácter meramente paleográfico? Ya hemos indicado que las opciones paleográficas distan de ser meramente «pictóricas», y que llevan aparejadas diferencias de otros órdenes (convendrá volver sobre esto).

Otros códices de posible origen toledano no están en la misma línea, y ejemplo podría ser el Fuero de Alcalá. No sabemos exactamente dónde se confeccionó, y no puede descartarse del todo la elaboración en el concejo de Alcalá de Henares. Pero ciertos elementos como la realista figura del arzobispo Jiménez de Rada enmarcada en la I capital de «In nomine» de la invocación que abre el libro, la letra, de módulo compacto, aunque las astas se prolonguen más que en la libraria, recuerdan usos extendidos en diversos monasterios castellanos, pero ni mucho menos está en la línea de la escritura cancilleresca, ni tampoco propiamente de la gótica libraria o «littera textualis». El examen gráfico-fonético, llevado a cabo para este fuero de manera exhaustiva por M. J. Torrens confirma plenamente esta diversidad.

En Toledo el modo tradicional de escribir romance es el representado, al menos en lo que toca al tipo de letra, por los documentos de 1219 del AMT. Esa letra que hemos considerado «típicamente toledana» es menos estilizada

\footnotetext{
145 «Los orígenes del español escrito», art. cit. Cabe recordar a Forto, escribano del cabildo y copista de libros (págs. 146-147).

146 Véase la lámina XII de Los cartularios de Toledo..., op. cit. El cartulario AHN 996B es fechado por Ramón Gonzálvez en el primer cuarto del s. XIII (ibíd., Prólogo, XX). Me atrevo a sugerir una datación algo posterior para 996B, ante la gran similitud con BNM 816 de la Primera Parte de la General estoria, de hacia 1275. Para la cronología de la gótica libraria es fundamental el art. de María Jesús Torrens, «La paleografía como instrumento de datación...», art. cit.
} 
que la de los diplomas regios, aunque prolonga sus astas más que la libraria, y menos angulosa que ambas; la curvatura de las astas es un rasgo definitorio. Quizá sea la letra usual de las escribanías mozárabes cuando escriben romance. ¿De dónde procede esa letra «toledana»? Creo quimérico pensar que proviene de un uso anterior a la reconquista ${ }^{147}$. La comparación con escritos de otras zonas apunta a un engarce con el uso de otros monasterios situados al norte del Tajo (y del Duero). Esta escritura toledana típica está igualmente representada en el cabildo, por los menos desde la década de los 20 del s. XIII.

La paleografía acierta a darnos una visión global de la escritura romance en Toledo, y nos permite subrayar su complejidad, y desde luego comprobar que arzobispado y cabildo no pueden considerarse un solo ente. Pero el examen de la grafía y de los otros niveles lingüísticos permitirá corroborar esta impresión. Lo que sí se ve claramente es la diferente valoración de latín y romance como códigos de escritura en el último tercio del s. XII y el primero del s. XIII, pues el carácter más humilde del documento se asocia con el uso del romance, y sólo raramente éste se presenta en la mejor caligrafía. Los usos son variados, y podríamos establecer una variada tipología textual asociada a tipos de letra (según su ejecución) que va de las bulas a los documentos de compraventa. Naturalmente, aquí nos interesan los tipos compartidos por latín y romance; el ámbito de las donaciones, cambios y cartas de compraventa muestra el predominio del tipo que aquí hemos llamado «toledano», de ejecución irregular tanto en la versión latina como romance.

Comparativamente, pueden extraerse deducciones más seguras del plano paleográfico que del gráfico, pues la heterogeneidad de las grafías en un mismo documento, su falta de sistematicidad, dificulta establecer filiaciones o, al menos, conexiones entre diferentes escritorios, e incluso entre diplomas producidos en el mismo centro. Creo que puede ponerse en duda la especificidad gráfica de la producción toledana. Ni siquiera los documentos que podrían considerarse próximos a la órbita mozárabe presentan características diferenciales... y no los presenta el Auto de los Reyes Magos, que tal vez tras lo visto aquí haya que retrasar a los primeros años del s. XIII, pero que Wright vinculaba a uno de los hermanos Apollechén, con cargo en la catedral «a pesar de» ser miembro de una poderosa familia mozárabe. $\mathrm{Ni}$ el uso de ch del Auto para /k/ ni de $k$ para este mismo valor en la carta-puebla de Villa Algariva son hallazgos toledanos, y, por lo que parece, antes se emplearon en el monasterio de Santa María de Aguilar. Pero sería aventurado dar por probada una dependencia directa, y no quisiera contribuir a remplazar viejas mixtificaciones por otras

\footnotetext{
147 A estas alturas se entenderá por qué llamo letra «toledana» a la de los documentos generalmente romances de finales del s. XII y de la primera mitad del XIII, frente a la denominación tradicional de «toledana» para referirse a la letra visigótica o «antigua», según una tradición que viene del s. XIII, al menos, y que se manifiesta en la General estoria.
} 
nuevas. En el estado actual de la investigación, creo que el examen gráfico no apoya la peculiaridad toledana, pero sin que sea posible, al menos por ahora, establecer con precisión el origen de esos usos, seguramente porque los movimientos de población, y en particular dentro de las comunidades religiosas, fueron especialmente frecuentes en el período que nos ocupa.

Tampoco es factible hablar sin más de progresiva fijación de la norma gráfica, como si este fuera un proceso de selección natural; antes bien, un hecho cultural está sometido a tendencias dispares e incluso contradictorias. Es más, los parámetros que «regulan» la grafía medieval, o mejor dicho, anterior al s. XIV, no son los actuales. Hoy la uniformidad ortográfica se considera un valor positivo; en la época que nos ocupa, la tendencia innegable a la adecuación grafía-fonética se ve contrarrestada por la «variatio», aparentemente no valorable como indicador positivo de conciencia del uso escrito, pero que estoy cada vez más convencido de que sí lo es (y la prueba está en su presencia en otros niveles, lo que da transcendencia mucho mayor, hasta convertirse en una clave interpretativa de la alternancia de código latín romance: casa $\sim$ domus en el Fuero de Belinchón).

La letra «toledana típica», la que, al parecer, se empleó en las escribanías mozárabes, no conduce a la usada en la cancillería oficial de Castilla. Es la mejor letra latina la que desemboca en la letra de privilegios y cartas plomadas luego escritas en romance. Esa escritura cancilleresca nace de un feliz maridaje entre la letra estilizada empleada en códices de los centros latinos de mejor latinidad, que, en definitiva, son los de cultura cluniacense. Por supuesto, para entender cómo se produce finalmente hay que atender a la tipología de los escritos. Está claro que el romance sólo se aplica inicialmente a la escritura de los documentos más humildes, y sin duda la paleografía nos da en esto una clave interpretativa mejor que la de nuestro juicio acerca de la importancia del asunto tratado, siempre valorable subjetivamente. Sólo hacia 1230 encontramos documentos romances en estupenda letra. Son justamente los de la cancillería de Fernando III.

Es necesario ver los usos gráficos concretos toledanos en comparación con los llamados «alfonsíes» (atendiendo, por lo dicho, a los diplomas de Fernando III). Así, el reparto entre $c$ y ç no puede decirse que en la Cancillería y en la Cámara Regia de Alfonso X se cumplan siempre. Los documentos de la Catedral de Toledo son bastante irregulares, pues ç se emplea frecuentemente ante $e, i$. Tampoco son mucho más regulares los códices patrocinados por Alfonso X (considerando sólo los verdaderamente confeccionados en su escritorio). En cambio, los diplomas regios suelen ser más constantes, aunque justo es reconocer que a ello contribuye su mayor brevedad.

Con todo, el estudio de la conexiones entre catedral de Toledo, cancillería regia y, más adelante, escritorio alfonsí no puede limitarse a la configuración 
del sistema de escritura, sino que habrá de abarcar los rasgos de lengua, de la fonética a la sintaxis y a a la configuración discursiva. Sólo de este modo podremos situar el castellano de la documentación toledana dentro de la historia de la lengua española. A ello atenderemos en un próximo estudio. 